\title{
Banks' Financial Conditions and the Transmission of Monetary Policy: A FAVAR Approach*
}

\author{
Ramona Jimborean and Jean-Stéphane Mésonnier \\ Banque de France
}

\begin{abstract}
We propose a novel approach to assess whether banks' financial conditions, as reflected by bank-level information, matter for the transmission of monetary policy, while reconciling the micro and macro levels of analysis. We include factors summarizing large sets of individual bank balance sheet ratios in a standard factor-augmented vector autoregression model (FAVAR) of the French economy. We first find that factors extracted from banks' liquidity and leverage ratios predict macroeconomic fluctuations. This suggests a potential scope for macroprudential policies aimed at dampening the procyclical effects of adjustments in banks' balance sheet structures. However, we also find that fluctuations in bank ratio factors are largely irrelevant for the transmission of monetary shocks. Thus, there is little point in monitoring the information
\end{abstract}

${ }^{*}$ We would like to thank Karim Barhoumi, Florin Bilbiie, Stefano Neri, Tao Zha, and an anonymous referee, as well as participants at the Second IJCB Financial Stability Conference on the Theory and Practice of Macroprudential Supervision hosted by the Banco de Espana (Madrid), the 2010 CEA Conference (Quebec), the 2010 Transmission Channel workshop of the Basel Committee Research Task Force (Paris), and seminars at the Banque de France and the European Central Bank, for valuable comments and suggestions. We are also grateful to Benoît Mojon and Dalibor Stevanovic for sharing their codes with us. Jocelyne Tanguy provided excellent research assistance. Last but not least, we thank our colleagues from the French Supervisory Authority for granting us access to the BAFI database and, in particular, Stéphane Chouard who coded the requested extraction numbers. The views expressed in this paper are those of the authors and do not necessarily reflect those of the Banque de France. Corresponding author: Mésonnier. Address: Banque de France, Financial Economics Research Division, 41-1391 Recfin, 39 rue Croix des Petits-Champs, 75001 Paris. Author E-mails: Mésonnier: jean-stephane.mesonnier@banque-france.fr; Jimborean: ramona.jimborean@banque-france.fr. 
contained in bank balance sheets, above the information already contained in credit aggregates, as far as monetary policy transmission is concerned.

JEL Codes: E44, E52, G21.

\section{Introduction}

The sub-prime crisis and the fears of a widespread credit crunch it has fueled over 2008-09 in most developed economies have highlighted the importance of sound financial conditions of banks for the ability of monetary policy rate cuts to effectively curb the contraction in credit supply to the economy. Over the last decade, the dominant view of the monetary policy transmission mechanism mainly pointed to the importance of the expectations channel of monetary policy, where monetary policy influences output and prices merely through the expected path of future short-term rates. ${ }^{1}$ By contrast, the recent crisis helped dramatically to revive the complementary "credit" view, according to which banks' individual reactions to monetary policy decisions matter much for the overall level of activity. As in previous episodes of wide-ranging bank capital depletion, like in the United States in the early 1990s or in Japan later in that decade (cf. Bernanke and Lown 1991; Woo 2003), empirical assessments of the bank lending and bank capital channels have recently gained a heightened attention in both academic and policy circles (see, e.g., Adrian and Shin 2009c).

However, the practical relevance of the credit channel for monetary policy has been one of the most fiercely debated empirical issues in monetary policy for at least two decades. ${ }^{2}$ Broadly speaking, empirical research has followed two main routes so far-one based on detailed individual bank information, the other based on measures of credit at the aggregate level - but both remain relatively inconclusive regarding the macroeconomic significance of financial frictions at the bank's level. We propose here a new approach that reconciles the use of both types of data: microeconomic bank data

\footnotetext{
${ }^{1}$ See, for instance, Blinder (1998), Bernanke (2004), and Woodford (2005).

${ }^{2}$ For a general perspective on the credit channel issue and the usual distinction between the so-called bank lending channel and the balance sheet channel of monetary policy transmission, see Bernanke and Gertler (1995). For a view of this debate at the euro-area level, see Angeloni, Kashyap, and Mojon (2003).
} 
for a large population of French banks and a rich macroeconomic database for France. While the choice of this country is partly dictated by issues of data availability, testing the importance of banks' financial conditions for monetary policy transmission is of particular interest in the case of France because its financial system is (still) largely bank based rather than market based.

As hinted above, a first strand of the applied literature has endeavored to identify the role of bank heterogeneity and loan supply effects at the micro level, running panel data regressions on bank balance sheet data in order to investigate the determinants of individual credit fluctuations (see, for instance, Kashyap and Stein 1995; Ehrmann et al. 2001). These studies have highlighted the impact of several banks' characteristics, such as total assets' size, capitalization, and liquidity ratios, on a differentiated response of bank loans to monetary policy shocks. Typically, the traditional bank lending channel of monetary policy transmission appears then to be stronger for small, poorly capitalized, and/or less liquid credit institutions. ${ }^{3}$ However, a limit to the policy relevance of this literature is that little can be inferred from the results of micro data studies about the macro consequences of bank balance sheet constraints. As argued by Ashcraft (2006), on the basis of such panel data regressions, one cannot tell whether the financial frictions at play in the bank lending channel and affecting, for instance, small banks really do account for a significant part of the dampening of real activity that follows a monetary policy tightening.

A second strand of the literature then relies on the estimation of small monetary vector autoregressions (VARs) at the macro level, following notably Bernanke and Blinder (1992). ${ }^{4}$ Indeed, impulse response functions (IRFs) derived from simple structural VAR models that factor in a few macro variables (e.g., GDP, inflation, and a measure of the policy stance) provide a useful device for evaluating monetary policy transmission. By adding a credit aggregate variable to this basic framework, it should be easy to gauge the impact of

\footnotetext{
${ }^{3}$ See, for instance, Kishan and Opiela (2000), Gambacorta and Mistrulli (2004), and Engler et al. (2005) for the United States, Italy, and Austria, respectively, and Loupias, Savignac, and Sevestre (2002) for France.

${ }^{4}$ See also Ramey (1993), as well as Ehrmann and Worms (2004), Hülsewig, Winker, and Worms (2004), and Den Haan, Sumner, and Yamashiro (2007), for more recent contributions.
} 
monetary policy shocks on total credit and the role of credit supply restrictions in economic downturns. In practice, however, things turn out to be trickier.

First, the estimated response of total bank loans to a monetary policy shock appears often to be muted and non-significant (Bernanke and Gertler 1995). A closer inspection of the dynamics of various aggregate bank credit series - contrasting, e.g., loans to households versus loans to non-financial firms, or short-term versus long-term loans - shows that this may result from a compensation effect of diverging responses of the main components in banks' loan portfolios (Den Haan, Sumner, and Yamashiro 2007; Mésonnier 2008). In turn, this hints that a small VAR including only one credit variable is probably misspecified. A solution to this misspecification problem could then be to add several aggregate loan series to the VAR; but, as is well known, the inclusion of additional variables in standard VARs is restricted by the degrees-of-freedom problems. ${ }^{5}$ Second, the information basis contained in a standard VAR with a handful of macroeconomic and aggregate credit variables appears to be too narrow, so that a proper identification of credit supply effects remains out of reach. As a matter of fact, by using a simple VAR framework, it is generally not possible to tell whether credit contracts after an interest rate hike because banks face a deteriorated balance sheet and then ration some borrowers within a process of deleveraging (loan supply effect) or because the deteriorated outlook has shifted down the demand for bank credit (loan demand effect). Overall, these limitations suggest that an empirical strategy that would rely on a data-rich environment à la Stock and Watson (2002) and would exploit information on heterogeneity in individual banks' financial conditions and the way they change through time could be more appropriate to detect the potential active role of banks in the transmission of the monetary policy shocks.

In this paper, we propose to examine the strength of the credit channel while reconciling the micro and macro levels of analysis into an integrated estimation framework. Following Bernanke, Boivin, and Eliasz (henceforth BBE) (2005) and Boivin and Gianonni (2009), we employ a factor-augmented vector autoregression model

\footnotetext{
${ }^{5}$ Nevertheless, Giannone, Lenza, and Reichlin (2009) propose to overcome this dimensionality problem and estimate such a large-scale monetary VAR using Bayesian techniques.
} 
(FAVAR) that we extend to explicitly include factors reflecting relevant fluctuations in a set of individual bank balance sheet ratios. A key feature of the BBE framework is to extract estimates of macroeconomic factors that affect the data of interest by exploiting the information contained in a large set of economic indicators. According to BBE (2005), the FAVAR framework leads to a better identification of the monetary policy shock compared with standard VARs, since it accounts explicitly for the large information set that central banks monitor in practice and also because it does not require taking an ex ante stand on the appropriate measure of economic concepts such as inflation or real activity, which are treated as latent common components. Finally, another appealing feature of the FAVAR approach is that the impulse response functions to a monetary policy shock can be computed for any variable included in the data set, while the dimensionality of the estimated VAR is kept reasonably low.

We implement this methodology in the case of France over the period 1993-2009, with quarterly data. The novelty of our approach consists in the parallel extraction of dynamic factors from large data sets of bank balance sheet indicators. Using French supervisory sources, we construct an original database of disaggregated bank financial ratios for a large set of French credit institutions, making up 70 percent of total domestic bank credit. We consider this way, in our application, the information contained both in a macroeconomic database comprising a large number of macroeconomic indicators and in a microeconomic database. We then use the FAVAR setup to quantify the specific impact of banks' financial conditions, if any, on the response of key macroeconomic variables to monetary policy shocks.

While our methodology closely follows that of Boivin and Gianonni (2009), who focus on the role of international factors in the transmission of U.S. monetary policy, our interest in the role of bank-level information is, to our knowledge, quite a novelty in the FAVAR literature. We are aware of only a few recent studies that go along a similar route. Gilchrist, Yankov, and Zakrajsek (2009) extract unobserved factors from a broad array of corporate bond spreads and study the macroeconomic impact of shocks to these measures of credit risk in a FAVAR model of the U.S. economy. Boivin, Gianonni, and Stevanovic (2009) perform a similar exercise but implement a different identification scheme of credit 
shocks which allows an economic interpretation of the (transformed) principal component analysis (PCA) factors. While close in spirit to ours, these studies do not, however, deal directly with monetary policy transmission and do not consider disaggregated bank data. By contrast, Dave, Dressler, and Zhang (2009) investigate the dynamic response of both credit aggregates and bank-level loan growth measures to a monetary policy shock using disaggregated U.S. bank data. However, they mainly focus on the differentiated responses of different types of loans, in the spirit of Den Haan, Sumner, and Yamashiro (2007), and do not use their FAVAR model to assess, as we do, whether fluctuations in banks' financial conditions (and their dispersion) significantly alter the transmission of monetary shocks to the broader macro economy.

Thematically, our work, of course, fits in with the abundant credit channel literature. However, more specifically, it can be related to a series of recent attempts to bridge the gap between microeconomic information about the health of financial institutions and the macro economy. Among these are recent studies by Adrian and Shin (2009a) that highlight the procyclical role of U.S. investment banks' leverage, as well as somewhat earlier research by Peek, Rosengren, and Tootell $(1999,2003)$, who use a summary of U.S. bank-level supervisory information to identify the effect of loan supply shocks on GDP and its main sub-components. ${ }^{6}$ The latter notably find that bank supervisory information predicts macroeconomic fluctuations, and they provide evidence that this information is in fact used by the Federal Reserve to conduct monetary policy. However, they do not formally examine the consequences of fluctuations in their bank health indicator for the transmission of monetary shocks.

Our main results are twofold. First, it appears that the first two principal components extracted from banks' liquidity or leverage ratios are quite correlated with industrial production and housing market conditions and that they predict macroeconomic fluctuations. This suggests a potential scope for macroprudential policies aiming at dampening the procyclical effects of changes in banks' balance sheet structures. Second, we nevertheless find that the fluctuations in banks' financial conditions do not matter much per se for

\footnotetext{
${ }^{6}$ Their summary variable is the percentage share of bank assets that fall within the CAMEL 5 rating computed by the U.S. Federal Reserve (i.e., the share of the riskiest part of the regulated U.S. banking system).
} 
the transmission of monetary policy shocks to the French economy. In other words, there is little point in monitoring the information contained in bank balance sheets above the information already contained in credit aggregates, as far as monetary policy transmission is concerned.

The rest of the paper is organized as follows. Section 2 reviews the econometric framework and the estimation approach, with a detailed presentation of the data used in our estimation. In section 3 we present the latent factors and the co-movements between the macro and micro factors. Section 4 investigates the role of the banklevel factors in the monetary policy transmission mechanism. Section 5 concludes.

\section{Econometric Framework: FAVAR}

We aim to evaluate the importance of individual banks' financial conditions for monetary policy transmission in the case of France, a country for which we have access to a rich supervisory database. In other words, we seek to estimate to what extent the specific response of banks' financial conditions enhances or mitigates the effect of monetary policy on the economy. In this section, we first describe the empirical model and the estimation approach. In so doing, we closely follow the lines of Boivin and Giannoni (2009).

\subsection{Description of FAVAR}

We consider an econometric framework based on a standard macro FAVAR model that we extend to include additional factors summarizing the financial health of individual banks. We assume that the macroeconomic conditions can be adequately summarized by a $K \times 1$ vector of unobserved components or factors, $C_{t}$, while another $K^{*} \times 1$ vector of factors $C_{t}^{*}$ is enough to describe the financial conditions of the banking sector. Note that, in what follows, the variables related to microeconomic information on banks will always be denoted with a star $(*)$. In practice, we can assess the state of the economy and the health status of resident banks using (i) a large vector of macroeconomic indicators (denoted by $X_{t}$ ) and (ii) a vector of individual bank balance sheet indicators for a large number of banks (denoted by $X_{t}^{*}$ ). These vectors are of dimension $N \times 1$ and $N^{*} \times 1$, respectively. 
We assume that the macroeconomic indicators are related to the state of the economy and that disaggregated bank balance sheet ratios are related to the overall financial conditions of the banking sector according to the following observation equations:

$$
\begin{aligned}
X_{t} & =\Lambda C_{t}+e_{t} \\
X_{t}^{*} & =\Lambda^{*} C_{t}^{*}+e_{t}^{*},
\end{aligned}
$$

where $\Lambda$ and $\Lambda^{*}$ are matrices of factor loadings and the $N \times 1$ (and $N^{*} \times 1$ ) vectors $e_{t}$ and $e_{t}^{*}$ stand for (mean-zero) series-specific components. By construction, these specific terms are uncorrelated with the common components $C_{t}$ or $C_{t}^{*}$ within each equation but are allowed to be serially correlated and (weakly) correlated across indicators. Note that the number of common factors is assumed to be small relative to the number of indicators $\left(N>K\right.$ and $\left.N^{*}>K^{*}\right)$. Within this framework, $C_{t}$ and $C_{t}^{*}$ represent two sets of components, common to all data series in each block and, in general, correlated across the two sides of the economy (macro conditions versus bank financial conditions).

The common factors should be understood as pervasive forces that drive the common dynamics of the data in each block, summarizing at each date either the state of the "real" economy or the financial strength of banks, as reflected by equations (1) and (2). The variables in $X_{t}$ are then taken as noisy measures of the underlying unobserved factors $C_{t}$. This means, for instance, that GDP growth, which belongs to the vector of macro series, is a noisy measure of "real activity," while the liquidity or leverage ratio of a bank $j$, which belongs to the vector of banking sector series, is a noisy measure of the financial health of the overall banking sector. We note that, in principle, it is not restrictive to assume that $X_{t}$ depends only on the current values of the factors, since $C_{t}$ might capture arbitrary lags of some fundamental factors. ${ }^{7}$

The dynamics of the common factors-i.e., the transition equation - are modeled as a structural VAR:

$$
\Phi_{0}\left[\begin{array}{c}
C_{t}^{*} \\
C_{t}
\end{array}\right]=\Phi(L)\left[\begin{array}{l}
C_{t-1}^{*} \\
C_{t-1}
\end{array}\right]+\left[\begin{array}{c}
v_{t}^{*} \\
v_{t}
\end{array}\right],
$$

\footnotetext{
${ }^{7}$ Stock and Watson (1999) refer to (1) as a dynamic factor model.
} 
where $\Phi_{0}$ is a matrix of appropriate size on which we later impose some restrictions, $\Phi(L)$ is a lag polynomial of finite order, and the "structural" shocks $v_{t}$ and $v_{t}^{*}$ are assumed to be i.i.d. with zero mean and diagonal covariance matrix $Q$ and $Q^{*}$, respectively. These shocks are uncorrelated, but any one of them may affect common factors of the other block (French economy versus banks' financial conditions) immediately or over time, through the off-diagonal elements of $\Phi_{0}$ and $\Phi(L)$. By pre-multiplying both sides of (3) by $\Phi_{0}^{-1}$, the structural VAR has then the following reduced-form representation:

$$
\left[\begin{array}{c}
C_{t}^{*} \\
C_{t}
\end{array}\right]=\left[\begin{array}{ll}
\Psi_{11}(L) & \Psi_{12}(L) \\
\Psi_{21}(L) & \Psi_{22}(L)
\end{array}\right]\left[\begin{array}{l}
C_{t-1}^{*} \\
C_{t-1}
\end{array}\right]+\left[\begin{array}{l}
u_{t}^{*} \\
u_{t}
\end{array}\right]
$$

where the reduced-form innovations $u_{t}$ and $u_{t}^{*}$ may be crosscorrelated.

Since we are interested in characterizing the effects of monetary policy on the economy, we want to include in the vector of macroeconomic common components an observable measure of the monetary policy stance. As is commonly the case in VAR studies of monetary policy in European countries, we consider here that the three-month money market rate, $R_{t}$, (i.e., the three-month PIBOR before 1999 and the three-month EURIBOR afterwards) is an appropriate measure of the monetary policy stance in France over the period from 1993 to 2009. The short-term interest rate is thus allowed to have a pervasive effect throughout the economy and is considered a common component of all macro data series. This way, we can write

$$
C_{t}=\left[\begin{array}{l}
F_{t} \\
R_{t}
\end{array}\right]
$$

where $F_{t}$ is a vector of latent macroeconomic factors summarizing the behavior of the rest of the French economy.

\subsection{Estimation}

We estimate the empirical model using Boivin and Gianonni's (2009) variant of the two-step principal component approach developed notably by Stock and Watson (2002) and BBE (2005).

The first step consists of extracting separately principal components from $X_{t}$ and $X_{t}^{*}$ in order to obtain consistent estimates of 
the common factors under the structure laid out. As stated above, we impose the constraint that the short-term interest rate is one of the factors for the set of macroeconomic series. This guarantees that the other estimated latent factors recover dimensions of the common dynamics that are not captured by the short-term interest rate. Starting from an initial estimate of $F_{t}$, denoted by $F_{t}^{(0)}$ and obtained as the first $K-1$ principal components, we thus iterate through the following steps:

(i) Regress $X_{t}$ on $F_{t}^{(0)}$ and $R_{t}$, to obtain $\hat{\lambda}_{R}^{(0)}$.

(ii) Compute $\tilde{X}_{t}^{(0)}=X_{t}-\hat{\lambda}_{R}^{(0)} R_{t}$.

(iii) Estimate $F_{t}^{(1)}$ as the first $K-1$ principal components of $\tilde{X}_{t}^{(0)}$.

(iv) Return to step (i).

As far as the common factors spanning individual bank balance sheet data are concerned, we do not impose any constraint in the first step. We simply estimate $F_{t}^{*}$ as the first $K^{*}$ principal components of $X_{t}^{*}$, where $X_{t}^{*}$ collects series of individual bank ratios as explained below in the data section.

In the second step, the short-term rate is added to the estimated macroeconomic factors $F_{t}$ and the VAR in $C_{t}$ and $C_{t}^{*}$ (equation (4)) is estimated. The matrix polynomial $\Psi_{21}(L)$ is then of particular interest, since it captures the lagged effect of banking conditions on macroeconomic factors. Note that the VAR coefficients $\Psi_{i j}(L)$ are identified, provided that the variance-covariance matrix of the innovations $\left[u_{t}^{*^{\prime}}, u_{t}^{\prime}\right]^{\prime}$ is non-singular. In particular, a sufficient condition for the coefficients in $\Psi_{21}(L)$ to be identified is that the factors standing for banking conditions do Granger-cause macroeconomic factors, an issue that we explore below.

\subsection{Data Description}

We use two distinct sets of data for the estimation of the FAVAR: a bank-level one and a macroeconomic one, both over the period 1993:Q2 to 2009:Q1, with quarterly frequency. Regarding the first data set, a distinctive feature of our study is that we make use of a large database of disaggregated bank balance sheet information as collected by the French supervisory agency (Commission bancaire). This database is particularly attractive because of its exhaustive 
coverage of all credit institutions chartered in France. ${ }^{8}$ Nevertheless, its time depth is limited - bank balance sheet details are only available (with this broad coverage and under consistent reporting guidelines) since the first quarter of 1993. Although this tends to limit econometric investigations, it may also be noted that the year 1993 coincides with the adoption of the Bank of France's independence by law, as well as with the launch of the last stage of the convergence process toward the European Monetary Union (EMU). This way, the period from 1993 to 2009 may be seen more convincingly as a single monetary policy regime, without any significant structural break (a point that we will discuss more in depth below, while presenting the impulse response functions computed from the FAVAR).

The macroeconomic data set comprises sixty-eight macroeconomic series - sixty series for the French economy and eight series for the German economy. All macro series have been transformed to induce stationarity when necessary, as indicated in the appendix. Other details about data sources and definitions are also provided in the appendix. The inclusion of some key German series is motivated by the fact that the French monetary policy was largely tied to the monetary policy of the German Bundesbank during the run-up to the EMU and, notably, from 1993 on, within the frame of the European exchange rate mechanism. Including measures of both French and German activity, inflation, and money prevents the implicitly estimated monetary policy function within the FAVAR from suffering significant structural breaks due to the introduction of the euro and the consecutive delegation of the French monetary policy to the European Central Bank (ECB). In particular, we rely on the fact that both countries, taken together, account for roughly half of the GDP of the entire euro area and behave (partly by construction) in a quite similar way to the euro-area average, which is the relevant aggregation level for the ECB since 1999.

Our initial bank-level data set, with some 620 credit institutions at sample end, is not directly suitable for the purpose of factor analysis because of (i) the high degree of heterogeneity between

\footnotetext{
${ }^{8}$ Note that this balance sheet information is collected on a territorial basis, which means that credit granted by subsidiaries of French banking groups abroad is not reported.
} 
institutions of different types and (ii) the wide-ranging process of concentration within the French banking sector during the 1990s: indeed, the number of institutions shrank by a factor of 2.5 over the period from 1993 to 2009, implying that many banks were not observable over the whole period. Selecting an adequate sub-sample of banks involves thus a difficult trade-off. The right balance has to be struck between, on the first hand, keeping enough individual banks to catch something of the dispersion of banks' financial conditions in the estimated factors, and, on the second hand, discarding enough atypical small institutions so that the few PC factors we extract from the final sample are economically meaningful.

To alleviate the heterogeneity issue and focus on "banks" as commonly understood (i.e., credit institutions whose business is to some large extent to collect deposits from the public and grant credits to non-financial agents), we first removed several categories of specialized credit institutions. These special categories include specialized financial institutions (such as leasing banks, customer credit institutions, factoring institutions, etc.), municipal credit institutions, and regional development institutions. We also dropped the regional branches of the three large mutualist and cooperative banks (in order to avoid double-counting when the group head also reports for the entire network), the regional savings banks affiliated with a large savings bank network (whose individual ratios were suspected to be affected by important within-network transfers), and the branches of foreign-held commercial banks (whose credit policy and financial health may be relatively immune to local economic conditions). ${ }^{9}$ Finally, we also dropped commercial banks that operate only in the French overseas territories. Overall, this preliminary cleaning leaves us with a population of 105 banks at sample end, accounting for 77 percent of total customer credit and 79 percent of total assets in the initial database. ${ }^{10}$

At this stage of the database cleaning process, the population of banks remains still very heterogenous in terms of assets'

\footnotetext{
${ }^{9}$ For instance, Peek and Rosengren (2000) show that the lending capacity of branches of Japanese banks in the United States, in the late 1990s, was heavily constrained by the capital crunch faced by the mother institutions in Japan, leading to severe restrictions in the U.S. commercial mortgage market.

${ }^{10}$ Customer credit is defined throughout as loans to non-banks in the supervisory database.
} 
size and business profile. A quarter of these institutions are very small banks - mainly private banks, local banks, or specialized institutions - with total assets below €500 million each at sample end. Since the unobserved factors $C_{t}^{*}$ are extracted by unweighted principal components analysis, keeping so many small banks implies that the information from the small banks' ratios (that have little macroeconomic significance but are often more volatile) can have a disproportionate bearing on the estimated factors, which would be detrimental to their economic significativity. We thus chose to drop from the above selected categories the banks belonging to the first quartile in terms of mean total assets. ${ }^{11}$ Besides, as the FAVAR approach requires a balanced data set, we are forced to keep only the banks for which we have data over the entire period 1993-2009. ${ }^{12}$

Combined, these two steps reduced the population to a sample of sixty banks, making up nearly 71 percent of total customer credit (and 71 percent of total bank assets). For each of these banks, we constructed three different financial ratios as defined below in more detail. Finally, a visual inspection of these ratios, cross-checked with the results of standard Bai and Perron tests of mean stability, revealed large statistical breaks for about half of these institutions, the bulk of them being again smaller banks accounting together for some 2 percent of total credit. We could check that these breaks are generally not explained by either acquisitions or changes of regulatory category but may reflect other sources of statistical noise like changes in capital detention or business lines, about which we have no information in the database. We thus decided to correct for the biggest breaks using a simple statistical procedure along the lines of Den Haan, Sumner, and Yamashiro (2007). More precisely, for each

\footnotetext{
${ }^{11}$ The twenty-six banks thus discarded have average total assets below $€ 405$ million over 1993-2009.

${ }^{12}$ In so doing, we obviously created a potential for a selection bias problem. An alternative, often considered in papers running panel regressions on individual bank data, consists of reconstructing mergers and acquisitions (M\&As) backward in time, in order to keep information both from target and buying banks before the M\&A (cf., for instance, Loupias, Savignac, and Sevestre 2002). This approach means in practice adding the corresponding balance sheet items of both banks prior to the merger. We think this method would be inappropriate for the purpose of our analysis, since it would end up creating individual measures of banks' financial health that did not exist in reality, adding uncontrolled sources of noise into the data.
} 
ratio data set, we computed growth rates of the ratio series and identified outliers as values distant from the cross-sectional mean by more than 2.63 standard deviations. We replaced these outlier growth rates with the corresponding cross-sectional means. Index ratio series were then reconstructed using the corrected growth rates and starting from the initial level values of the ratios. Finally, we dropped eight banks, mainly market banks, that presented more than 20 percent outliers for at least one of the ratios. ${ }^{13}$

The resulting final sample consists of fifty-two commercial and cooperative banks accounting for 70 percent of total loans granted by all credit institutions at sample end (and 69 percent of total assets). Figure 1 shows the share of our sample in the total of bank loans over the whole period (1993:Q1-2009:Q1). This share increased somehow through time, staying between 66 percent and 70 percent since early 1997.

For each bank in the sample, we define three ratios that capture key dimensions of a bank's financial situation: one liquidity ratio and two leverage ratios - a total (or broad) leverage ratio and a credit (or narrow) leverage ratio. Both types of ratios have been identified in the empirical panel literature as important determinants of banks' reaction to monetary policy shocks, in line with the standard descriptions of the credit channel and the renewed versions of the same theory (like the bank capital channel of Van den Heuvel 2002). The introduction of total leverage ratios is also motivated by Adrian and Shin's (2009b) recent findings that the total leverage of at least some U.S. credit institutions is highly procyclical and their proposal that banks' leverage should be more closely and systematically monitored in a macroprudential perspective. ${ }^{14}$

We compute firstly an indicator of bank liquidity (labeled LIQ in the following), which we define as the ratio of liquid assets to total assets. Liquid assets are computed as the sum of cash, interbanking transactions, securities bought under repurchase agreements, and securities held in the trading portfolio.

\footnotetext{
${ }^{13}$ In the final ratio data sets, the outlier detection procedure implied a correction of 3 percent of the observations in the case of the broad leverage ratio and less than 2 percent for the other ratios.

${ }^{14}$ Regulatory capital ratios would have been equally interesting candidates, but this information was not available with enough time depth to be used in a time-series analysis.
} 


\section{Figure 1. Share of the Banks in Sample in Total Loans Granted by All Resident Credit Institutions, 1993-2009}

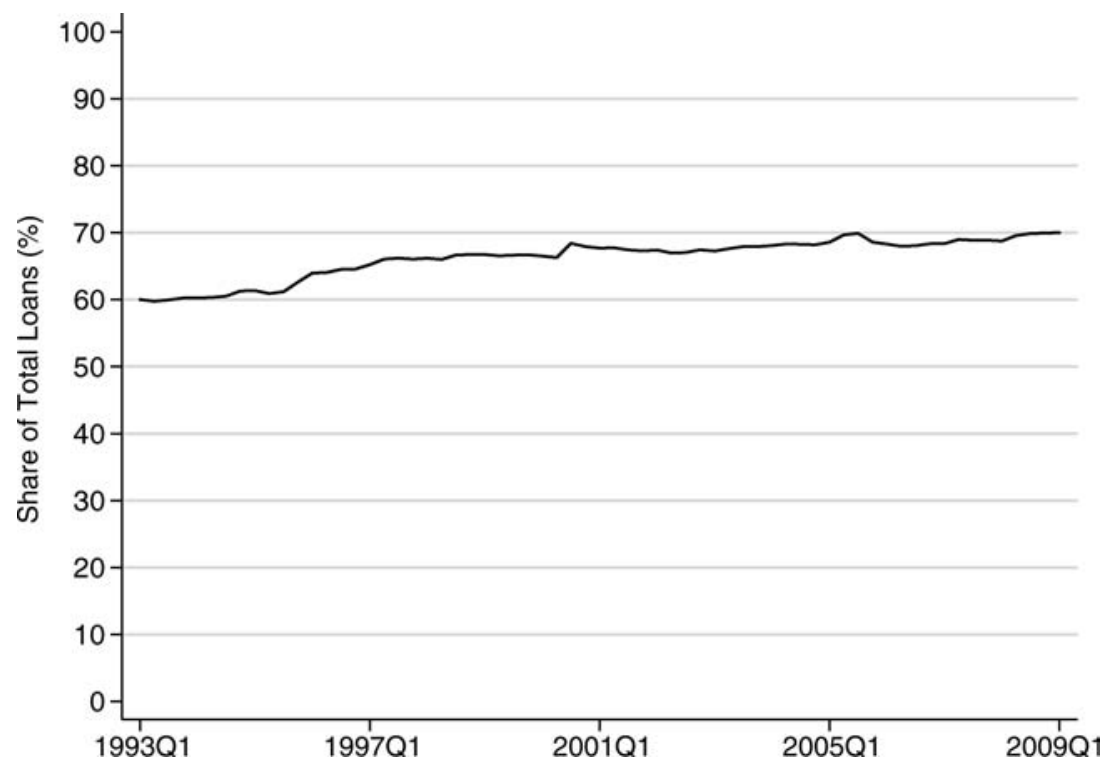

Secondly, we define our broad measure of leverage (LEV1) as the ratio of total assets to tier 1 capital. This broad leverage ratio is thus the inverse of the capitalization ratio often considered in earlier panel data studies. ${ }^{15}$ Finally, we also compute a narrow measure of leverage (LEV2), defined as the ratio of customer credit to tier 1 capital. Although less frequently used in the academic literature, this second leverage ratio is monitored by the French regulators on a regular basis, which motivates its inclusion in our study. ${ }^{16}$

Table 1 presents some descriptive statistics for our sample in 1999:Q1. Note that the sample, although relatively small and centered on banks of relatively close types, is still quite diverse along the standard dimensions explored by the credit channel literature, be it in terms of size (with total assets ranging from € 268 million

\footnotetext{
${ }^{15}$ See, for instance, Kishan and Opiela (2000) and Loupias, Savignac, and Sevestre (2002) for the French case.

${ }^{16} \mathrm{Cf}$., for instance, Commission bancaire (2009, p. 69 et seq.)
} 


\section{Table 1. Descriptive Statistics (2009:Q1)}

\begin{tabular}{|l|c|c|c|c|c|}
\hline & Mean & Median & SD & Min. & Max. \\
\hline Assets (Billions of Euros) & 99.5 & 5.4 & 255 & 0.3 & 1,390 \\
\% of Total Bank Assets & 1.3 & 0.1 & 3.4 & 0.0 & 18.6 \\
Loans (Billions of Euros) & 27.1 & 1.9 & 62.9 & 0.0 & 334 \\
\% of Total Bank Loans & 1.4 & 0.1 & 3.1 & 0.0 & 16.6 \\
Liquidity (LIQ) & 0.22 & 0.29 & 0.23 & 0.01 & 0.99 \\
Broad Leverage (LEV1) & 20.5 & 29.1 & 26.1 & 1.18 & 124.7 \\
Narrow Leverage (LEV2) & 8.0 & 11.6 & 11.23 & 0.18 & 50.52 \\
\hline
\end{tabular}

to $€ 1,390$ billion), liquidity (with a ratio between 1 percent and 99 percent), or leverage (with a broad ratio between 1.2 and 125).

Factor estimation using principal components requires stationary times series. ${ }^{17}$ Although it seems reasonable to assume from an economic point of view that bank ratios should be stationary, standard unit-root tests reveal that it is not always the case from a statistical point of view in our sample. ${ }^{18}$ Neglecting the results of such tests and keeping stochastic trends in the ratio data sets may lead to inconsistent estimates of the bank ratio factors and spurious correlations of these factors with the most persistent macroeconomic series in our database -in particular, interest rates. We thus took the first difference of the individual ratio series that showed a unit root at the 95 percent probability level, and left other ratios series unchanged. ${ }^{19}$ Last, note that, following common practice, all macro and micro series were demeaned and standardized before extraction of the factors by PCA.

\subsection{Specification of the FAVAR}

The empirical model presented above is a dynamic factor model that links a large set of observable indicators to a small set of common

\footnotetext{
${ }^{17}$ Although simple methods have been proposed to estimate consistent factors from non-stationary panel data (see the PANIC methodology by Bai and $\mathrm{Ng}$ 2004), such methods are not suited for data sets mixing stationary and non-stationary series. Besides, the FAVAR approach requires stationary factors.

${ }^{18}$ We ran augmented Dickey-Fuller tests with a constant and a number of lags selected according to the Akaike information criterion.

${ }^{19}$ Between 64 percent and 83 percent of the ratios were considered as having a unit root, depending on the type of ratio.
} 
components through the observation equations (1) and (2). The evolution of the common components is then specified by the transition equation (3) or its reduced-form representation (4). Theoretically, to the extent that we keep a sufficiently large number of common components from the PCA of each data block, the estimated factors collected in $C_{t}$ and $C_{t}^{*}$ span the same space as the unknown "true" factors or latent variables that drive the set of noisy indicators $X_{t}$ and $X_{t}^{*}$. The issue of the number of factors selected is thus an important one in theory. In practice, however, there is still no clear consensus about the right analytical criteria for the choice of this number, and numerous applications rely on judgmental or empirical evidence like, for instance, the change induced to the estimated impulse response functions when new factors (accounting for a smaller part of the database variance) are added to the FAVAR model. $^{20}$

In our case, it should be borne in mind that the class of specifications we can consider is severely constrained by the sample size (sixty-four quarters of observations), which especially limits the number of lags in (4) as the number of factors gets larger. We want to include more than one common component from a given bank ratio data set, in order to assess the potential impact of bank heterogeneity on the economy. Nevertheless, small sample size prevents us from including simultaneously common components from all three ratio data sets. We do then consider three distinct FAVAR models, replacing $X_{t}^{*}$ with each of the three ratio data sets in turn.

We thus based the choice of the number of factors on two empirical criteria. Firstly, we computed Bai and Ng (2002) PCP2 and IC2 criteria, which indicated a maximum number of two factors for each of the three ratio data sets for the baseline sample of banks. Secondly, for each type of bank ratio, we estimated a FAVAR with up to six macroeconomic factors (including the short rate) and up to three common components from individual bank series. It appears that the form of the IRF to monetary policy shocks is quite robust to the inclusion of additional factors when at least four macro factors are included in the model. Whatever the bank ratio considered, our preferred specification of the corresponding FAVAR thus includes four

\footnotetext{
${ }^{20}$ This is the route followed, e.g., by BBE (2005), Boivin, Giannoni, and Mojon (2008), and Boivin and Giannoni (2009).
} 
macroeconomic factors and two bank ratio factors, and the transition equation (4) has one lag. ${ }^{21}$

\section{Bank Balance Sheet Factors and Macroeconomic Dynamics}

We first aim at clarifying how the factors summarizing French macroeconomic dynamics relate to disaggregated bank-level factors, as extracted separately from three microeconomic data sets of individual liquidity and leverage ratios. In this section, we thus use the common factors extracted from our various data sets and first determine the fraction of fluctuations in indicators of real activity, inflation, credit aggregates, and interest rates that can be explained by macro and bank-level factors, respectively. This first simple look at correlations and Granger causalities suggests that there is potentially a scope for a macroprudential regulation of banks' leverage and liquidity with a view of limiting the extent of macroeconomic fluctuations induced by banks' behavior. In the next section, we will then compare the impulse responses of various key macroeconomic variables when bank ratio factors are allowed to interact with macro factors or alternatively when this additional feedback mechanism is artificially shut down.

\subsection{Interpreting the Latent Factors: A First Look}

We start by examining how the macro and bank ratio or micro factors are correlated with each other and with key macro variables, in an attempt to roughly characterize these latent factors. Figure 2 shows the estimated macro factors, while the bank ratio factors are plotted in figures $3-5$.

Table 2 reports the correlations of the first three macro factors (excluding of course the short-term interest rate, which we force to be the fourth macro factor as explained above) with a selection of macroeconomic variables. The first latent macro factor obviously

\footnotetext{
${ }^{21}$ Results from standard tests of lag selection were mixed. The Schwarz information criterion suggested one lag in the various FAVAR models, generally in line with the Hannan-Quinn criterion, while the Akaike information criterion suggested from two to five lags, depending on the model.
} 


\section{Figure 2. Macro Factors}

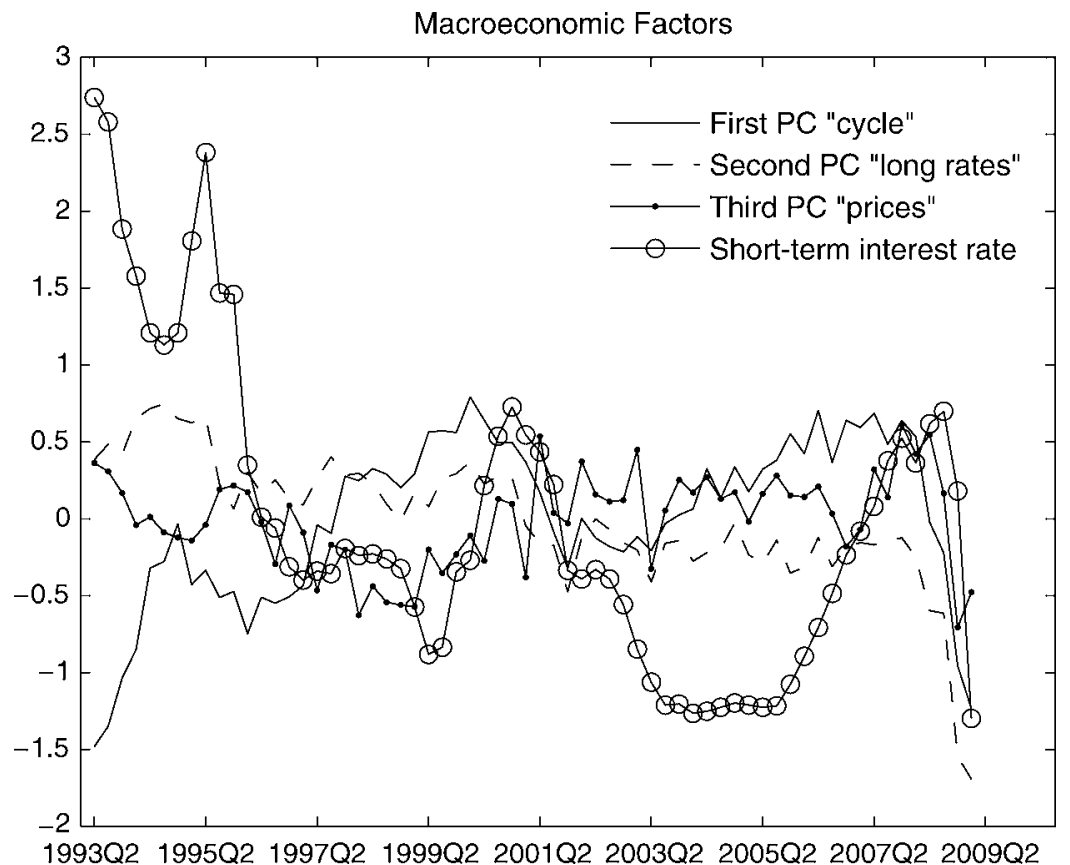

stands for a measure of the business cycle, with a high positive correlation to GDP growth and its components and a negative correlation to unemployment. The second macro factor is also positively correlated with GDP growth but can be more easily characterized as driven by longer-term interest rates, while the third macro factor tends to capture the dynamics of inflation.

Table 3 reports the correlation of the micro factors, as extracted separately from each of the three bank ratio data sets, with the macro factors. The first LIQ component is strongly correlated with the business cycle macro factor (and, with opposite sign, with the short-term interest rate), while the second bank liquidity component is mostly correlated with the second macro "long-term rate" factor, and the correlation coefficient is smaller. The second LEV1 factor and the first LEV2 factor have similar correlation profiles and are strongly correlated with the short-term interest rate. The other two leverage factors are also correlated with the "interest rate" and 
Figure 3. LIQ Factors

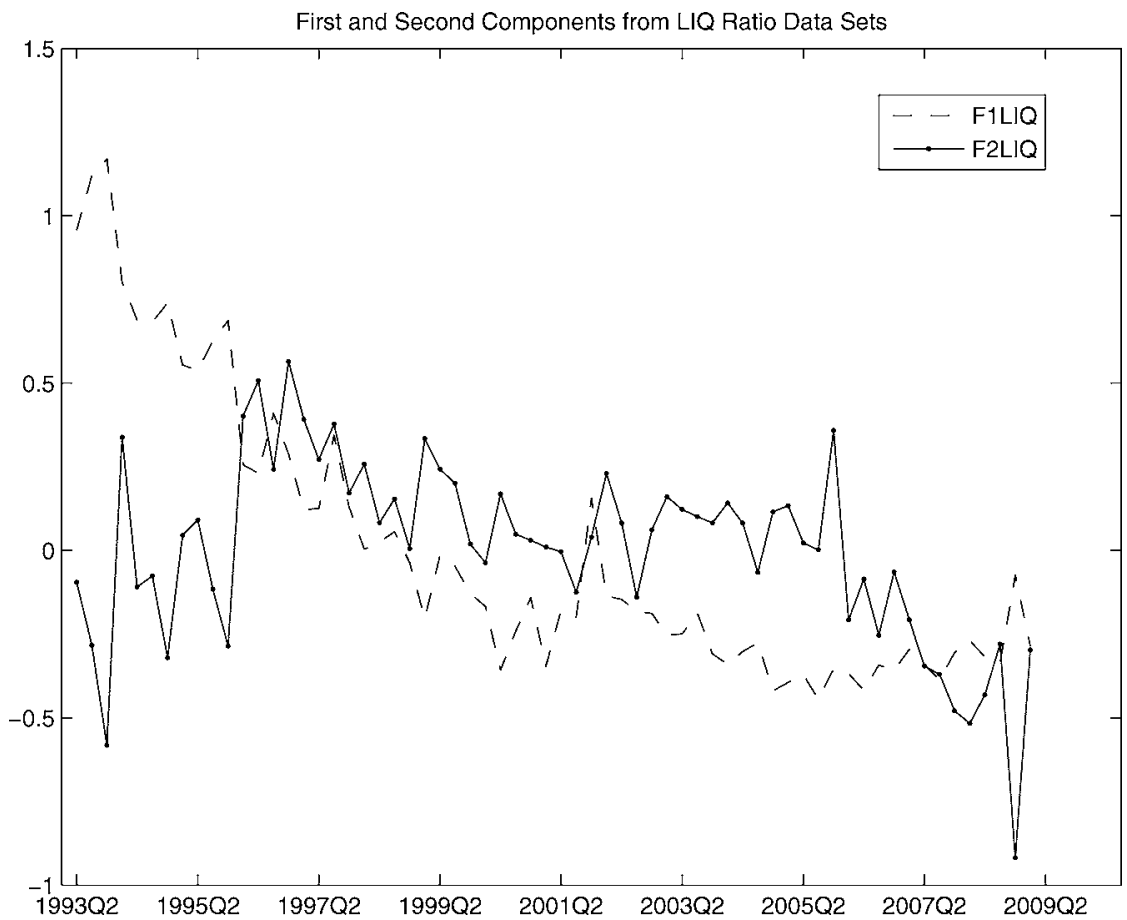

"business cycle" macro factors, but the correlation is weaker. Overall, these preliminary calculations confirm the intuition that banks adjust key dimensions of their balance sheets to fluctuations in real activity and market interest rate conditions. We do not know, however, to what extent such adjustments are active, as part of their asset-liability management policy, or passive, as an effect of changes in demand for credit. Neither can we determine on the basis of this evidence alone whether changes in bank conditions have an impact on macro conditions.

\subsection{Co-Movements between Macro and Micro Factors}

In a second step, we investigate to what extent French macroeconomic variables are explained by macro versus bank-based factors. To do this, we regress each macro variable on the three macro factors 


\section{Figure 4. LEV1 Factors}

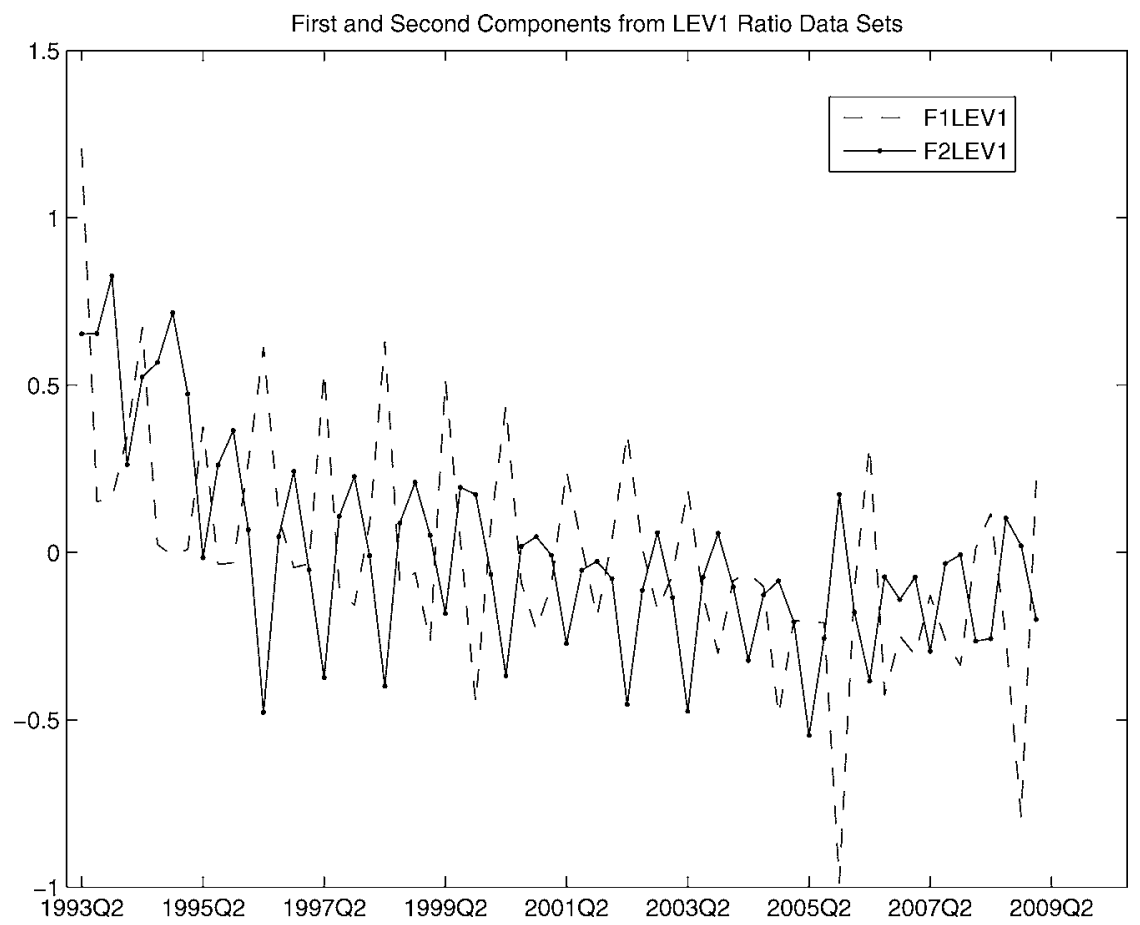

(including the short-term interest rate) or the first two bank-based factors obtained for a given type of bank ratio, taking each type of ratio in turn. Table 4 reports the fraction of variance of the series listed (i.e., the $R^{2}$ of the least-squares regressions) that is explained by the macro factors and the bank ratio factors of each type (i.e., either related to liquidity or leverage, broadly or narrowly defined), respectively.

As is apparent in the first row of the table, the entire macroeconomic data set, $X_{t}$, is on average strongly correlated with the common factors. The $R^{2}$ of the macro factors is of 0.56 , showing that the macro factors capture a good part of fluctuations in the French economy overall. As could be expected, the first three PCA factors of each set of individual bank ratios are less correlated with the macro series on average, with an $R^{2}$ of between 0.11 and 0.28 , depending on the type of bank ratio considered. 


\section{Figure 5. LEV2 Factors}

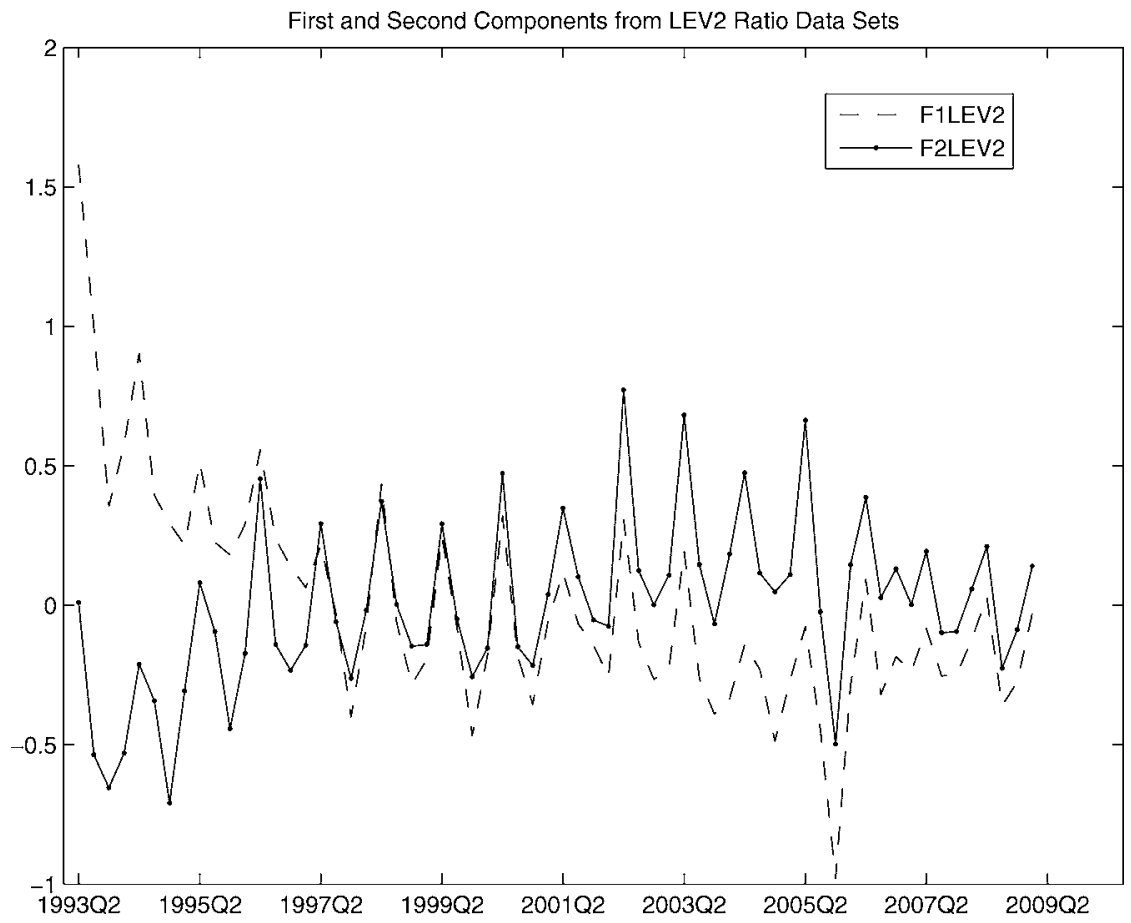

When looking more closely at selected macroeconomic indicators, we first find that quarterly growth rates of real GDP, industrial production, HICP inflation, employment, and non-residential investment present high correlations with the macro factors $\left(R^{2}\right.$ statistics of $0.84,0.87,0.81,0.80$, and 0.67 , respectively), while it is far less so for consumption (be it consumption of durable or nondurable goods). Macro factors also do a good job in tracking market and credit interest rates. The important point here is that most of the fluctuations in very cyclical variables are captured by only four macro factors. Note that the macro factors also explain some 62 percent of the variance in housing prices and 70 percent of the variance in housing loans.

Regarding the results of regressions on bank-level common components, we first find that bank liquidity and credit leverage factors explain a substantial part of the variance of housing prices (between 
Table 2. Correlations between the Macro Factors and Selected Macro Variables

\begin{tabular}{|l|r|r|r|}
\hline Variable & \multicolumn{1}{|c|}{ F1 } & \multicolumn{1}{|c|}{ F2 } & \multicolumn{1}{|c|}{ F3 } \\
\hline Interest Rate & -0.49 & 0.50 & 0.15 \\
GDP & 0.57 & 0.69 & -0.07 \\
Industrial Production Index & 0.79 & -0.44 & 0.22 \\
Employment & 0.75 & 0.39 & -0.23 \\
Unemployment & -0.65 & -0.42 & -0.02 \\
Consumption & 0.33 & 0.18 & -0.19 \\
Consumption Durable & 0.11 & 0.13 & -0.14 \\
Consumption Non-Durable & 0.06 & 0.12 & -0.10 \\
Non-Residential Investment & 0.67 & 0.43 & -0.18 \\
Inventories & 0.78 & -0.00 & 0.04 \\
Residential Investment by Household & 0.46 & 0.43 & -0.02 \\
Housing Prices & 0.58 & -0.02 & 0.25 \\
HICP & 0.16 & 0.17 & 0.87 \\
GDP Deflator & 0.20 & -0.28 & 0.54 \\
Total Loans & 0.61 & -0.20 & 0.33 \\
Housing Loans & 0.60 & -0.47 & 0.30 \\
Inv. Corporate Loans & 0.54 & -0.51 & 0.07 \\
C\&I Loans & 0.59 & 0.01 & 0.02 \\
France Ten-Year Yield & -0.48 & 0.71 & -0.01 \\
Interest Rate C\&I Loans & -0.57 & 0.60 & 0.08 \\
Interest Rate Invt. Loans & -0.72 & 0.55 & 0.13 \\
Interest Rate Housing Loans & -0.63 & 0.67 & -0.11 \\
\hline
\end{tabular}

Table 3. Correlation between Bank Ratio Factors and Macro Factors

\begin{tabular}{|l|c|c|c|c|c|c|}
\hline & F1 & F2 & F1 & F2 & F1 & F2 \\
Variables & LIQ & LIQ & LEV1 & LEV1 & LEV2 & LEV2 \\
\hline Fmacro1 & $-0.70^{* * *}$ & 0.07 & $-0.33^{* * *}$ & $-0.47^{* * *}$ & $-0.61^{* * *}$ & $0.29^{* *}$ \\
Fmacro2 & $0.61^{* * *}$ & $0.39^{* * *}$ & $0.40^{* * *}$ & $0.47^{* * *}$ & $0.47^{* * *}$ & $-0.35^{* * *}$ \\
Fmacro3 & -0.05 & $-0.21^{*}$ & 0.00 & -0.01 & 0.01 & 0.01 \\
Interest Rate & $0.76^{* * *}$ & $-0.31^{* *}$ & $0.38^{* * *}$ & $0.64^{* * *}$ & $0.67^{* * *}$ & $-0.49^{* * *}$ \\
\hline Notes: ${ }^{* *}$, and ${ }^{* * *}$ denote significance at the 10 percent, 5 percent, and 1 percent \\
level, respectively.
\end{tabular}


Table 4. $R^{2}$ for Regressions of Selected French Macro Indicators on Various Sets of Macro and Bank Ratio Factors (Sample 1993:Q2-2009:Q1)

\begin{tabular}{|l|c|c|c|c|}
\hline & $\begin{array}{c}\text { All Macro } \\
\text { Factors } \\
\mathbf{( 1 )}\end{array}$ & $\begin{array}{c}\text { LIQ } \\
\text { Factors } \\
\mathbf{( 2 )}\end{array}$ & $\begin{array}{c}\text { LEV1 } \\
\text { Factors } \\
\mathbf{( 3 )}\end{array}$ & $\begin{array}{c}\text { LEV2 } \\
\text { Factors } \\
\mathbf{( 4 )}\end{array}$ \\
\hline All France Data $\boldsymbol{X}_{\boldsymbol{t}}$ & & & & \\
(Average Over All & & & & \\
French Data) & & & & \\
\hline Selected FR Indicators & & & & \\
\hline Interest Rate & 1.00 & 0.68 & 0.56 & 0.69 \\
GDP & 0.84 & 0.16 & 0.02 & 0.00 \\
Industrial Production Index & 0.87 & 0.83 & 0.62 & 0.71 \\
Employment & 0.80 & 0.11 & 0.02 & 0.05 \\
Unemployment & 0.68 & 0.03 & 0.03 & 0.04 \\
Consumption & 0.19 & 0.05 & 0.01 & 0.03 \\
Consumption Durable & 0.05 & 0.01 & 0.03 & 0.01 \\
Consumption Non-Durable & 0.04 & 0.02 & 0.01 & 0.00 \\
Non-Residential Investment & 0.67 & 0.06 & 0.02 & 0.05 \\
Inventories & 0.69 & 0.27 & 0.23 & 0.26 \\
Residential Inv. by & & & & \\
Household & 0.46 & 0.06 & 0.01 & 0.01 \\
Housing Prices & 0.62 & 0.32 & 0.22 & 0.33 \\
HICP & 0.81 & 0.01 & 0.00 & 0.00 \\
GDP Deflator & 0.41 & 0.14 & 0.11 & 0.08 \\
Total Loans & 0.56 & 0.28 & 0.14 & 0.16 \\
Housing Loans & 0.70 & 0.57 & 0.43 & 0.48 \\
Inv. Corporate Loans & 0.60 & 0.49 & 0.25 & 0.33 \\
C\&I Loans & 0.45 & 0.13 & 0.08 & 0.08 \\
France Ten-Year Yield & 0.80 & 0.70 & 0.60 & 0.64 \\
Interest Rate C\&I Loans & 0.89 & 0.71 & 0.62 & 0.78 \\
Interest Rate Invt. Loans & 0.95 & 0.82 & 0.69 & 0.83 \\
Interest Rate Housing Loans & 0.91 & 0.85 & 0.75 & 0.79 \\
\hline
\end{tabular}

22 percent and 32 percent). The correlation with contemporaneous housing price growth, while saying nothing about the direction of causality, highlights the fact that the recent boom and bust in housing prices over the last decade was largely associated with changes 


\section{Table 5. Granger Causality Tests for Bank Factors Affecting Macro Factors}

\begin{tabular}{|l|c|c|c|}
\hline & LIQ & LEV1 & LEV2 \\
\hline All Sample (1993-2009) & & & \\
F1 & 0.92 & 0.00 & 0.00 \\
F2 & 0.00 & 0.15 & 0.08 \\
F3 & 0.50 & 0.89 & 0.86 \\
Interest Rate & 0.73 & 0.00 & 0.00 \\
\hline Before 2007-09 Crisis & & & 0.06 \\
F1 & 0.02 & 0.06 & 0.00 \\
F2 & 0.00 & 0.01 & 0.05 \\
F3 & 0.21 & 0.02 & 0.01 \\
Interest Rate & 0.21 & 0.00 & \\
\hline Note: Table reports p-values. & \multicolumn{3}{|l}{} \\
\hline
\end{tabular}

in individual banks' balance sheets. Rolling regressions over an eight-year period (not reproduced here to save space) show that this correlation was in fact higher, above 60 percent, over the decade from 1995 to 2005, which corresponds to the boom episode in France. Second, bank liquidity ratios are highly correlated with average bank interest rates for new loans, notably housing loans and investment loans to non-financial firms.

\subsection{Do Banks' Financial Conditions Predict Macro Fluctuations?}

The correlations discussed so far shed some light on the interrelation between macroeconomic conditions and the balance sheets of individual credit institutions. However, we do not know so far whether changes in banks' balance sheets are passively driven by the macro economy or whether they actively contribute to shaping the business cycle, as the bank lending channel would suggest, or at least can help to predict it.

In a first attempt at identifying the information content of banks' financial conditions for future macroeconomic conditions, we computed standard Granger causality tests within each of the three FAVAR models with bank ratio factors. Table 5 reports in rows 
the results of tests of the joint significance of bank-level factors of a given type (as stated in the column heads) in a regression of each macro factor over all lags of all macro factors and lags of the bank ratio components. Under the null hypothesis, bank-level factors have no predictive power. The upper panel reports results of estimations over the whole sample, while the lower panel restricts to the period before the onset of the sub-prime crisis in 2007:Q3.

The results show that the three types of bank ratios do not have the same informational content for macroeconomic conditions. The information extracted from narrow (respectively, large) bank leverage predicts three (two) of the macro factors over the whole period, and up to four macro factors over the pre-crisis period (at the 10 percent level). In particular, bank leverage factors consistently predict the short-term interest rate and the "business cycle" factor one quarter ahead. In contrast, factors summarizing bank liquidity mainly predict the second macro factor and, over the pre-crisis period, the "business cycle" factor. By the way, these results confirm that the coefficients $\Psi_{21}(L)$ in the reduced-form model (equation (4)) are determinate, at least some of them.

While preliminary, the outcome of these causality tests suggests that microprudential regulations of liquidity or leverage of credit institutions should also matter in a macroprudential perspective. ${ }^{22}$

\section{Implications for the Monetary Transmission Mechanism}

We have documented so far that common components from key individual banks' balance sheet ratios co-move with selected macroeconomic variables and, to some extent, drive changes in broad macroeconomic conditions. A natural question that arises then is whether the endogenous reaction of individual banks to an unexpected monetary policy impulse significantly alters the response of aggregate variables of interest (like GDP or consumer price inflation). The standard theory about the credit channel of monetary policy transmission suggests that the endogenous response of banks may amplify

\footnotetext{
${ }^{22}$ Note, however, that our measure of leverage is the total asset ratio to book equity capital, which significantly differs from the ratio of capital to risk-weighted assets usually monitored by bank supervisors.
} 
the effects of a monetary tightening, e.g., due to an increase in the external finance premium required by banks in the face of an induced deterioration of borrowers' creditworthiness (financial accelerator effects) or, similarly, a rise in the external finance premium faced by banks following an induced deterioration in their own assets' value (bank capital channel). Alternatively, theories of credit rationing suggest that capital shortages or liquidity constraints on the side of banks may, on the contrary, dampen the response of bank credit to monetary policy attempts at loosening overall financial conditions.

We investigate here this issue within the FAVAR framework presented above in section 2, following a general approach initiated by Boivin and Gianonni (2009). More precisely, we compare the impulse response functions (IRFs) of selected macroeconomic variables to a 100-basis-points monetary policy shock under alternative hypotheses regarding the coefficients $\Psi_{21}(L)$ in equation (4), which links macro factors to lagged bank-level factors. The difference between the IRF when this block of coefficients is set to zero and when it is left unrestricted provides a measure of how important the endogenous response of individual banks' balance sheets is for the monetary transmission mechanism in France. In other words, the larger the difference, the more a model of monetary policy transmission which includes only money and credit aggregates is misspecified.

A preliminary important issue is, however, whether the launch of the euro and the changeover from the Bank of France to the ECB from January 1999 on implies a regime shift for monetary policy in France or not. If it were the case, then non-linearities should arise (at least) in the short-term interest rate equation of our FAVAR, and we would not be allowed to investigate credit channel issues on the basis of linear VARs estimated over a time period that includes the date of EMU inception.

We think, however, that the assumption of no regime shift is amply vindicated in the case of France since 1993, the year when the Bank of France gained formal independence by law for the conduct of monetary policy. We base our position on both institutional and statistical arguments. First, as hinted above in section 2.3, French monetary policy was closely anchored to the policy conducted by the German Bundesbank and, indirectly, to German economic conditions between 1993 and 1999, only because of the commitment of the Bank of France to peg the French franc to the deutsche mark in order 


\section{Table 6. Multivariate Chow Tests of a Structural Break in 1999:Q1}

\begin{tabular}{|l|c|}
\hline & p-value (\%) \\
\hline Macro Factors Only & 0.26 \\
Macro + LIQ Factors & 0.56 \\
Macro + LEV1 Factors & 0.58 \\
Macro + LEV2 Factors & 0.57 \\
\hline Note: Bootstrapped p-values (5,000 replications). \\
\hline
\end{tabular}

to meet nominal convergence requirements during the run-up phase to the EMU. To reflect this, we included some key macroeconomic German series in our macro database, as detailed above in the data section. Second, French macro aggregates tend to co-move strongly with the (reconstructed) euro-area average since the mid-1990s. Since France and Germany both account for about 50 percent of overall euro-area GDP, one should be comfortable with the idea that our macro factors are both quite relevant as summary ingredients of the reaction function of the Bank of France before 1999 and highly correlated with the euro-area measures of activity and inflation the ECB is likely to respond to since 1999. Third, Boivin, Gianonni, and Mojon (2008) have shown that the launch of the euro did not significantly affect the transmission of monetary policy shock in France and Germany. Fourth and last, we carried out standard breakpoint tests for our FAVAR models, positing the first quarter of 1999 as a possible break date. Table 6 presents the results of multivariate Chow sample-split tests. As it is well known that such tests tend to over-reject the null of no break in samples of common sizes, we followed Candelon and Lütkepohl (2001) and computed bootstrapped p-values (with 5,000 replications). The results show that the null of no break in the FAVAR coefficients due to the inception of the euro is confirmed in all cases, at the 26 percent level for the "purely macro" model without bank factors and at levels above 56 percent for the models with LIQ, LEV1, and LEV2 bank-level factors.

Finally, figures 6,7 , and 8 show the estimated impulse response functions of selected macroeconomic indicators to an unexpected tightening of monetary policy. In each figure, the solid lines represent the responses computed for the FAVAR model based on the 


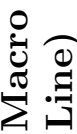
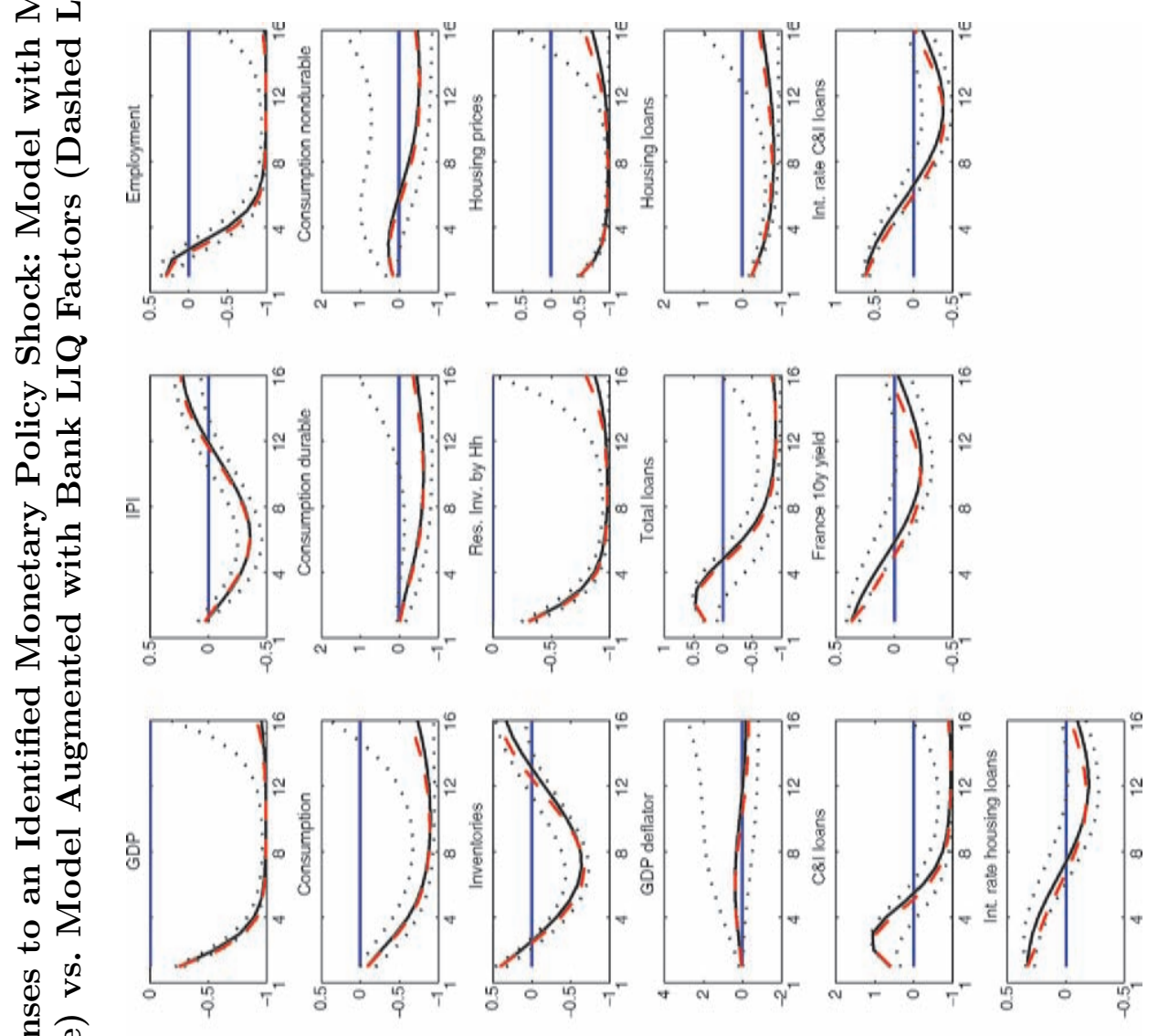

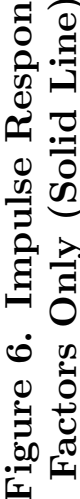
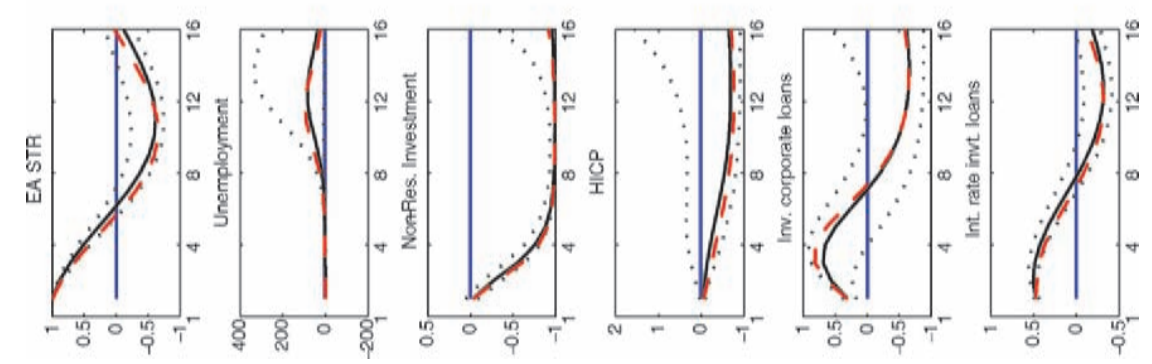


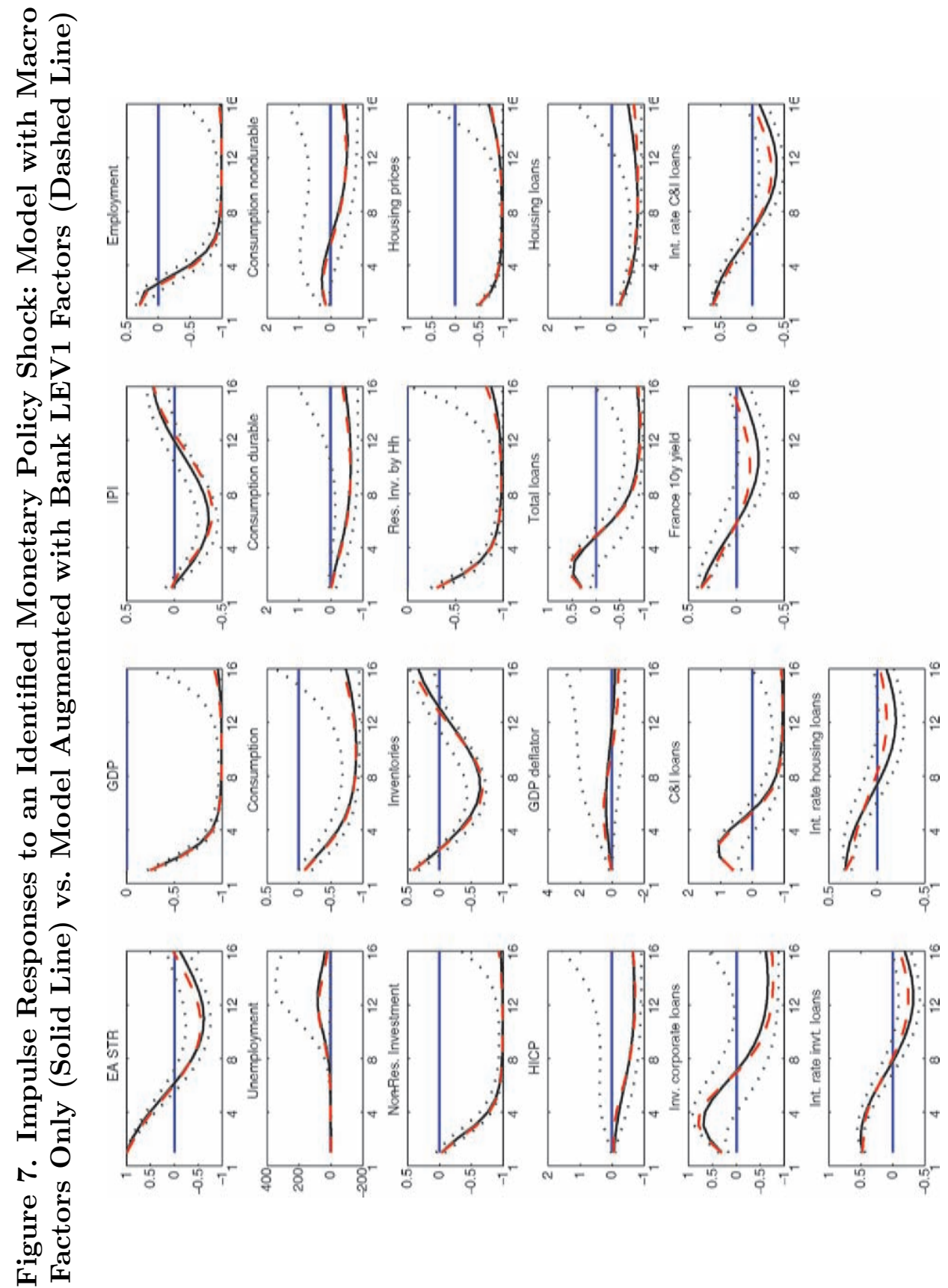


Vol. 6 No. 4

Banks' Financial Conditions

101

ํㅣㄹ

걸
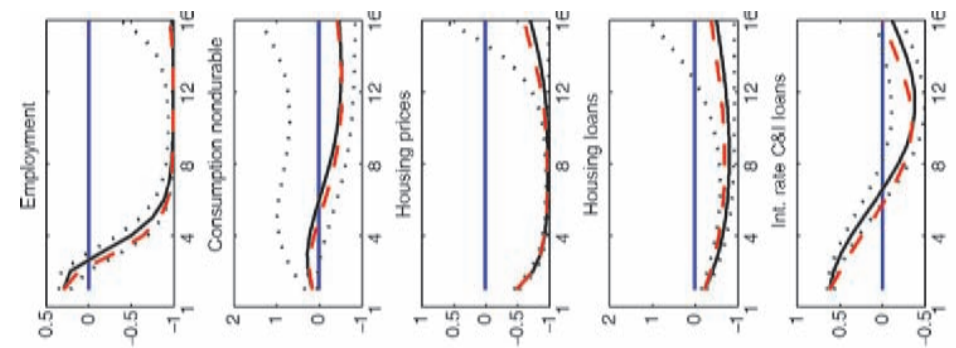

๘
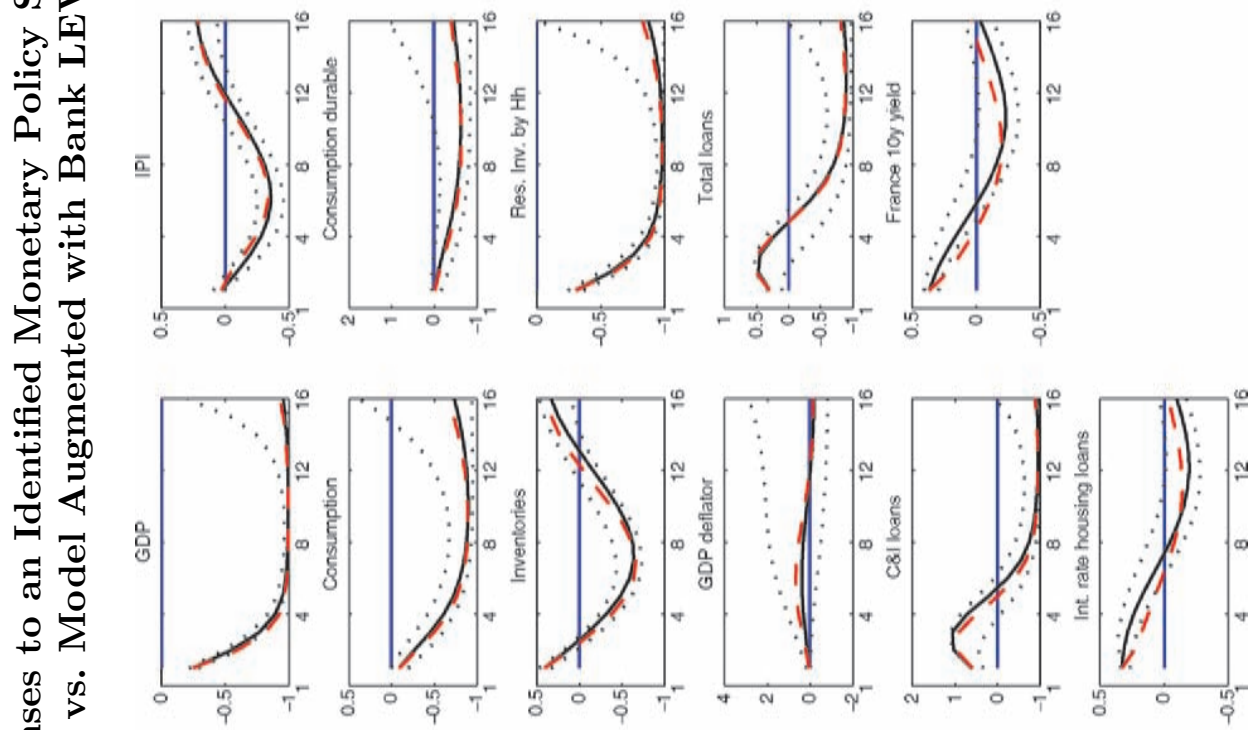

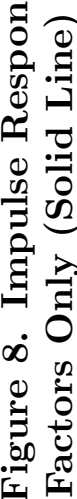
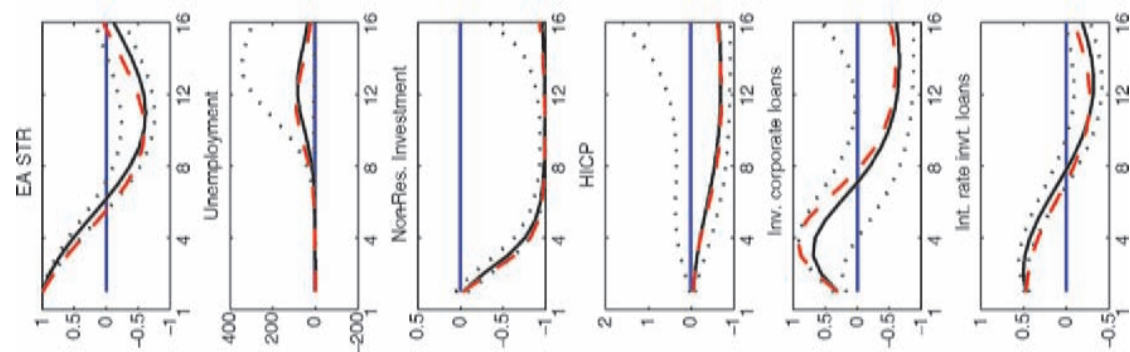
sole macro factors, while the dashed lines stand for the responses when the macro model is augmented with two common components extracted from one of the individual bank ratio data sets (LIQ, LEV1, and LEV2, respectively). The impulse responses are plotted along with the 70 percent confidence intervals. ${ }^{23}$

Regarding first the responses computed for the FAVAR model limited to the macro factors, the results look in line with usual findings and economic intuition. Following an unexpected monetary policy tightening, activity declines over the first six quarters and resumes slowly thereafter. Industrial production gets back to its original level within three years, while GDP reverts more slowly. Investment, either residential or not, and inventories react more than consumption, while within consumption, consumption of durables is more negatively affected by an interest rate hike than is the consumption of non-durable goods. The rate of unemployment reacts sluggishly, and employment, which reaches a low after three years, reverts very slowly to the original level, which may be consistent with conventional wisdom for France over this period. Interestingly, consumption prices as measured by the HICP decrease slowly over the first three years without the initial upswing or "price puzzle" that is often obtained within small macro VAR models. The response of the GDP deflator exhibits some price puzzle, but it is also more muted and globally non-significant. Housing prices react vigorously and on impact to an interest rate hike and reach their low within two years. Long-term government bond yield as well as the various bank loan interest rates also react positively on impact to the monetary policy tightening. Interest rates on commercial and industrial $(\mathrm{C} \& \mathrm{I})$ loans, which are mostly short-term loans indexed on short-term market rates, adjust almost completely, while the pass-through of the short rate to interest rates on housing loans, which are in France mostly long-term fixed-rate mortgage loans, is significantly positive but muted, in line with previous findings for this country. ${ }^{24}$ Regarding the response of the various types of bank loans at the aggregate

\footnotetext{
${ }^{23}$ We use Kilian's (1998) bootstrap procedure to compute the confidence intervals. Note that we bootstrap both the estimation of the factors and of the coefficients, so that the confidence intervals also account for estimation uncertainty about the unobserved factors.

${ }^{24}$ Cf., for instance, Coffinet (2005).
} 
level, housing loans decrease over the first two years, while corporate loans, and notably shorter-term C\&I loans, react positively in the short run and recede thereafter.

The "puzzling" positive response of short-term C\&I loans to a monetary tightening has already been documented on U.S. data (cf. Kashyap and Stein 1995; Morgan 1998; Den Haan, Sumner, and Yamashiro 2007). Several types of explanations for this temporary increase can be found in the literature. A first line of reasoning points to a demand effect by firms, which may have to finance an inventory buildup following a monetary tightening or have to bear temporarily a higher cost for their working capital (cf. Bernanke and Gertler 1995). Other authors look for supply effects by banks themselves, which may want to optimize the return on their credit portfolio and/or adjust their (risk-weighted) assets structure to keep complying with capital regulation in spite of the adverse effects of the monetary tightening on their interest revenues and hence on their equity base (cf. Van den Heuvel 2002; Den Haan, Sumner, and Yamashiro 2007). These banks would therefore shift their portfolio toward short-term loans and out of longer-term credit, which either typically yields fixed interest rates (like mortgage loans) or requires a higher capital coverage (like long-term loans to non-financial firms, at least under Basel I bank capital regulations). However, even if banks aim at reducing loan supply, this may be delayed by prevailing loan commitments to the benefits of larger firms, which account for the bulk of commercial bank credit. Indeed, large firms frequently borrow from commercial banks under loan commitment contracts so as to secure the volume and conditions of the loans they have over a pre-agreed period. As Morgan (1998) shows in the U.S. case, loans without commitments do contract after a tightening monetary policy shock, while small firms also complain about tighter credit conditions offered by banks. Meanwhile, loans under commitments do not falter, or they even increase. ${ }^{25}$ In our case, the significant positive short-term response of inventories points toward a dominant role of credit demand by firms in the positive response of C\&I loans to a monetary shock. Besides, the similar responses of these

\footnotetext{
${ }^{25}$ Note that the argument about loan commitments may also be relevant to explain the shape of the response of bank loans for investment purpose.
} 
loans in the macro FAVAR and in the model augmented for common components extracted from total leverage ratios (LEV1) hints that the potential bearing of loan supply effects due to bank capital constraints is limited here.

Overall, figures 6,7 , and 8 show that the responses in the models with bank-level ratio factors are very close, and at least not significantly different at the 70 percent level of confidence, to the responses obtained in the simpler models that include only macroeconomic information. Our exercise suggests thus that the specific reaction of individual banks to a monetary policy shock and the feedback of the induced changes in bank balance sheets on macroeconomic variables do not significantly alter the transmission process of monetary policy to the macro economy. This does not mean that the banking system and the way it interacts with non-financial private agents is a pure veil, but merely that the information already included in monetary macro variables like aggregate flows of bank credit for housing or corporate investment purpose is sufficient to capture the macroeconomic consequences of the credit channel. To that extent, the differentiated reactions to monetary policy shocks that are associated with heterogeneities in individual banks' balance sheet structures appear to be largely irrelevant from a macroeconomic point of view.

How do our findings relate with earlier literature? Considering the vast amount of studies on the credit channel, we find it more useful to focus this discussion on the differences between this study and two contributions by Ramey (1993) and Peek, Rosengren, and Tootell (1999, 2003), which have particularly close connections with two dimensions of our approach.

In a somewhat older paper, Ramey (1993) did a counterfactual exercise that is formally close to the one we conducted in this section. Using a small-scale VAR model of the U.S. economy with four variables (output, money, credit, and the federal funds rate), she sets alternatively to zero the coefficients of the policy variable in either the money or credit equation, which is equivalent, she claims, to shutting down either the money or credit channel of monetary transmission. She then compares the impulse responses of output to a policy shock she obtains with either of the restricted models to the impulse response from the unrestricted VAR and concludes that the credit channel is unimportant in explaining monetary transmission. In his discussion of her paper, Bernanke (1993) sharply criticizes 
Ramey's reading of her results, pointing out notably that (i) they are consistent with both the money and the credit views, as both views imply a quick reduction in bank liabilities, and that (ii) this device alone cannot solve the age-old identification issue of bank loan supply versus demand effects. Although we agree with Bernanke's points, we think that they do not apply to the results presented in this paper. First, we are not interested in assessing the relative strength of the money channel (or, to put it in more modern terms, of the interest rate channel) vis-à-vis the credit channel in the particular case of the French economy. Since our macroeconomic database includes a list of credit aggregates and bank loan interest rates as well as monetary aggregates, our (restricted) baseline FAVAR with only macro factors does not exclude the possibility of operative bank lending and balance sheet channels. Our point is merely to assess the macroeconomic relevance of findings of the empirical literature in the vein of Kashyap and Stein (2000), showing that individual banks with different characteristics in terms of, notably, liquidity and capitalization react differently to monetary shocks, which creates a potential for credit restrictions by at least some banks. Neither do we claim that we can identify (the absence of) loan supply effects using our methodology. Indeed, we cannot tell a priori whether changes in banks' financial conditions as captured by the factors are exogenous or driven by some other shocks to loan demand: even innovations to the second factors, which take more account of changes in heterogeneity of the ratios across banks, can reflect the adjustment to idiosyncratic (e.g., industry specific) shocks that affect the customers of some banks more than others and thus the demand for credit addressed to those banks. To conclude on this, we thus do not read our results as proving that loan supply effects are unimportant. Instead, we just conclude that, at least in normal times, this heterogeneity in banks' financial conditions does not matter much for explaining monetary transmission at the macro level.

More recently, Peek, Rosengren, and Tootell (1999, 2003) also tried to reconcile micro bank information with macro outcomes as they used detailed confidential supervisory information to construct an aggregate indicator of banks' financial health (the share of assets held by banks viewed by bank regulators as likely to fail, i.e., those with a "CAMEL" rating of 5). Running univariate regressions, they first find that their bank health variable (but no other summaries 
of bank leverage and liquidity ratios) contains useful marginal information to forecast unemployment and inflation up to four quarters ahead, which suggests that the Federal Reserve should look carefully at such bank-level information from supervisory sources to conduct monetary policy. On the basis of probit models of the Federal Reserve's target rate decisions, they also find that the Federal Reserve does actually take into account this information. In their second paper, they then provide evidence that shocks to their CAMEL indicator do reflect shocks to bank credit supply, which implies that part of the forecasting power of the bank health indicator for output has a causal interpretation. Our results contrast with theirs on two points. Firstly, contrary to part of their first findings, our Granger causality tests reported above suggest that even simple bank leverage ratios do help to improve forecasts of macroeconomic activity. Secondly and more importantly, Peek, Rosengren, and Tootell (2003) do not formally examine, as we do, the consequences of monetary policy shocks, although they point in their conclusion to the relevance of their study for quantitative assessments of the bank lending channel. Instead, they focus on the (difficult) task of identifying loan supply shocks per se and show that such effects matter for U.S. macroeconomic fluctuations. However, the mere fact that loan supply shocks exist and are important is a necessary but not a sufficient condition to prove that banks' reactions to monetary policy shocks, as a consequence of financial frictions that constrain adjustments to their balance sheets, do amplify the effects of the policy moves. Indeed, as Peek, Rosengren, and Tootell (2003) show that their findings are robust when the bank health indicator has been priorily orthogonalized with respect to the federal funds rate (and other state variables), one may think that it is the exogenous part in innovations to banks' health that matters (i.e., true loan supply shocks), not necessarily the endogenous reaction to other shocks. To conclude, their results do not contradict ours as far as the credit channel is concerned, but instead suggest interesting avenues for further research on the effects of shocks to banks' financial conditions using our FAVAR framework.

\section{Conclusion}

In this paper we aim to quantify whether changes in banks' financial conditions at the microeconomic level matter at the macroeconomic 
level, notably by altering the monetary policy transmission mechanism. Using a unique and comprehensive database of individual bank balance sheets, we set up a FAVAR framework that allows us to summarize both overall macroeconomic conditions in the French economy and the financial conditions of banks resident in France with a small number of factors.

Within this framework, we first provide evidence that the information contained in three types of individual bank financial ratioscapitalization, liquidity, and leverage ratios - explains a substantial part of macroeconomic fluctuations in some aggregate variables, most notably those related to the housing market (housing prices, residential investment, and housing loans). Moreover, we find that the first two principal components extracted from individual bank leverage and liquidity ratios have a significant predictive power for macroeconomic conditions, which suggests that there is potentially a scope for active macroprudential policies aimed at constraining changes in these ratios.

Finally, we compare the impulse response functions of alternative FAVAR models that either allow for or restrict the feedback effects of bank-level factors on macroeconomic ones. We find that the information contained in individual bank ratios, including changes in balance sheet heterogeneity among banks, does not matter much for the transmission of monetary policy shocks.

This work could be extended in at least three ways. First, instead of following the methodology of Boivin and Gianonni (2009), we could implement the recently developed dynamic hierarchical factor model of Ng, Moench, and Potter (2009), whose advantage consists in distinguishing series-specific variations from two types of common variations: those from factors that are common to units within a block, and those from factors that are common across blocks. This could allow us to simultaneously consider the inclusion of all three kinds of bank ratios within the same FAVAR model. Second, it could be interesting to look at the effects of real demand shocks and see whether bank factors are relevant for the transmission of such shocks to the economy (as per the financial accelerator hypothesis). Finally, taking stock of the results of causality tests presented here and as suggested above by our discussion of Peek, Rosengren, and Tootell (2003), we could investigate within a FAVAR framework the macroeconomic consequences of shocks to trends or dispersion in banks' 
leverage or liquidity conditions, in the spirit of the tests developed by Gilchrist, Yankov, and Zakrajsek (2009). This is left for further research.

\section{Appendix. Data Sets}

\section{Macroeconomic Series}

The format contains the series number; data span (in quarters); transformation code; and series description as appears in the database. The transformation codes are: 1 - no transformation; 5 - first difference of logarithm. The series were taken from the Monetary Statistics database of the Banque de France, the Bank for International Settlements (BIS), the Eurostat database, the IN/IP INSEE database, and the OI/OP OECD database.

\section{France}

1 1993:1-2009:1 1 EMU 3-month EURIBOR, total, end of period

2 1993:1-2009:1 5 Total loans of French credit institutions, SA

3 1993:1-2009:1 5 Total loans to NFIs, SA

4 1993:1-2009:1 5 Loans to NFIs for cash needs, SA

5 1993:1-2009:1 5 Loans to NFIs for investing needs, SA

6 1993:1-2009:1 5 Total loans to households, SA

7 1993:1-2009:1 5 Mortgage loans to households, SA

8 1993:1-2009:1 5 Monetary aggregate M3, outstanding amounts at the end of the period (stocks)

9 1993:1-2009:1 5 Gross domestic product at market price, chain linked volumes, reference year 2000, SA

10 1993:1-2009:1 1 Production of total industry, index, SA

11 1993:1-2009:1 5 Final consumption of households and NPISH's (private consumption), chain linked volumes, reference year 2000, SA

12 1993:1-2009:1 5 Private consumption of households, durable goods, chain linked volumes, reference year 2000, SA 
13 1993:1-2009:1 5 Private consumption of households, nondurable goods, chain linked volumes, reference year 2000, SA

14 1993:1-2009:1 5 Exports of goods and services, chained volume estimates, $\mathrm{SA}$

15 1993:1-2009:1 5 Imports of goods and services, chained volume estimates, $\mathrm{SA}$

$16 \quad$ 1993:1-2009:1 5 Gross fixed capital formation of financial institutions, goods and services, SA

17 1993:1-2009:1 5 Gross fixed capital formation of public services, goods and services, SA

18 1993:1-2009:1 5 Gross fixed capital formation of households, goods and services, SA

19 1993:1-2009:1 5 Gross fixed capital formation of households, building and civil engineering, SA

20 1993:1-2009:1 5 Gross fixed capital formation of households, real estate services, $\mathrm{SA}$

21 1993:1-2009:1 5 Gross fixed capital formation of NFIs, goods and services, $\mathrm{SA}$

22 1993:1-2009:1 5 Gross fixed capital formation of NFIs, building and civil engineering, SA

23 1993:1-2009:1 5 Gross fixed capital formation of all sectors, goods and services, $\mathrm{SA}$

24 1993:1-2009:1 5 Employees, full time equivalent, SA

25 1993:1-2009:1 5 Unemployment rate, BIT definition, SA

26 1993:1-2009:1 1 Increase in stocks, end of period (\%)

27 1993:1-2009:1 5 Construction costs, total, cost of materials, NSA, Index, 1953 Oct $=100$

28 1993:1-2009:1 5 Cost of construction: multiple dwellings, end of period

29 1993:1-2009:1 5 CAC40, end of day

30 1993:1-2009:1 5 Oil price, brent crude - 1 month forward, level

31 1993:1-2009:1 5 GDP Deflator, index publication base SA

32 1993:1-2009:1 5 Consumer price index, harmonised, SA

33 1993:1-2009:1 5 Consumer price index, end of period

34 1993:1-2009:1 5 CPI (households, base 1998) - Food and non-alcoholic drinks

35 1993:1-2009:1 5 CPI (households, base 1998)-Alcoholic drinks 
36 1993:1-2009:1 5 CPI (households, base 1998)-Clothing and footwear

37 1993:1-2009:1 5 CPI (households, base 1998)-Housing, water, gas, electricity and other combustibles

38 1993:1-2009:1 5 CPI (households, base 1998)- Furniture, domestic equipment and house keeping

39 1993:1-2009:1 5 CPI (households, base 1998)- Health

40 1993:1-2009:1 5 CPI (households, base 1998)- Transportation

41 1993:1-2009:1 5 CPI (households, base 1998) Communications

42 1993:1-2009:1 5 CPI (households, base 1998) - Leisure and culture

43 1993:1-2009:1 5 CPI (households, base 1998)-Hotels, cafes and restaurants

44 1993:1-2009:1 5 CPI (households, base 1998)- Other goods and services

45 1993:1-2009:1 5 PPI-Buldings

46 1993:1-2009:1 5 PPI-Extractive industry, energy, water, wastes management and depolluting

47 1993:1-2009:1 5 PPI-Manufacturing industry

48 1993:1-2009:1 1 Long-term interest rate on government bonds

49 1993:1-2009:1 1 Average rate on loans to NFIs < 1 year, new contracts

50 1993:1-2009:1 1 Average rate on loans to NFIs > 1 year, new contracts

51 1993:1-2009:1 1 Average rate on consumer loans to households, new contracts

52 1993:1-2009:1 1 Average rate on mortgage loans to households, new contracts

53 1993:1-2009:1 1 Consumer confidence indicator, SA

54 1993:1-2009:1 1 Food-processing industry-production capacity utilization, $\%, \mathrm{SA}$

55 1993:1-2009:1 1 Consumption goods industry - production capacity utilization, $\%$, SA

56 1993:1-2009:1 1 Automobile industry - production capacity utilization, \%, SA

57 1993:1-2009:1 1 Equipment industry-production capacity utilization, $\%$, SA 
58 1993:1-2009:1 1 Intermediary goods industry-production capacity utilization, $\%$, SA

59 1993:1-2009:1 1 Business climate in industry

60 1993:1-2009:1 1 Business climate in trade services

\section{Germany}

61 1993:1-2009:1 5 Monetary aggregate M2, outstanding amounts at the end of the period (stocks)

62 1993:1-2009:1 5 Gross domestic product at market price, chain linked volumes, reference year 2000 , SA

63 1993:1-2009:1 5 Employees, persons (Thousands, SA)

64 1993:1-2009:1 5 Unemployed persons (Thousands, SA)

65 1993:1-2009:1 5 Gross domestic product, implicit price deflator, SA

$66 \quad$ 1993:1-2009:1 5 HICP, SA

67 1993:1-2009:1 1 Consumer confidence indicator, SA

68 1993:1-2009:1 1 Long-term interest rate on government bonds

*NFI - non-financial institutions; NPISH - non-profit institutions serving households; PPI - Producer Price Index; SA - seasonally adjusted.

\section{Disaggregated Bank Balance Sheet Series}

The format contains the series number; data span (in quarters); bank identification code (CIB); and the name of the credit institutions as appears in the database. The ratios were computed using balance sheet information from the BAFI database of the French Banking Commission, Banque de France.

\section{Liquidity and Leverage Ratios}

\begin{tabular}{|c|c|c|}
\hline CIB & Period & Credit Institution \\
\hline 7 & $1993: 2-2009: 1$ & $\begin{array}{l}\text { CUMUL BQ POP HORS AGRE- } \\
\text { MENT COLLECTIF SCM }\end{array}$ \\
\hline 10057 & $1993: 2-2009: 1$ & $\begin{array}{l}\text { STE BORDELAISE DE CIT IND ET } \\
\text { COMMERCIAL }\end{array}$ \\
\hline 10096 & $1993: 2-2009: 1$ & LYONNAISE DE BANQUE L,B, \\
\hline 1017 & 1993:2-2009:1 & BANQUE CHAIX \\
\hline 1018 & 1993:2-2009:1 & BANQUE CHALUS \\
\hline
\end{tabular}


6

$9 \quad 10558$

$10 \quad 10638$

1993:2-2009:1

BANQUE LAYDERNIER

10228 1993:2-2009:1

BANQUE COURTOIS

1993:2-2009:1

BANQUE RHONE-ALPES

1993:2-2009:1

BANQUE TARNEAUD

$11 \quad 11188$

1993:2-2009:1

CREDIT COMMERCIAL DU

SUD-OUEST

\section{$12 \quad 11449$}

1993:2-2009:1

RCI BANQUE

$13 \quad 11808 \quad$ 1993:2-2009:1

BANQUE THEMIS

BANQUE FEDERATIVE DU

CREDIT MUTUEL

$14 \quad 12280 \quad$ 1993:2-2009:1 SOCRAM BANQUE

$15 \quad 12869 \quad 1993: 2-2009: 1 \quad$ BANQUE ACCORD

$16 \quad 12939 \quad 1993: 2-2009: 1$

$17 \quad 13259 \quad 1993: 2-2009: 1$

BANQUE DUPUY DE PARSEVAL

$18 \quad 13539$

1993:2-2009:1

BANQUE KOLB

$19 \quad 17290$

1993:2-2009:1

BANQUE SOLFEA

$20 \quad 17679$

1993:2-2009:1

DEXIA CREDIT LOCAL

STE DE BANQUE ET

D'EXPANSION-SBE (2EME)

$21 \quad 18029 \quad$ 1993:2-2009:1

BNP PARIBAS PERSONAL

FINANCE

$18189 \quad 1993: 2-2009: 1$

CIE GLE DE CIT AUX PARTIC-

ULIERS CREDIPAR

$23 \quad 18359 \quad 1993: 2-2009: 1$

OSEO FINANCEMENT

$24 \quad 18370 \quad 1993: 2-2009: 1$

BANQUE FINAMA

$25 \quad 18609 \quad$ 1993:2-2009:1

CAISSE CENTRALE CIT IMMOB

DE FRANCE-3CIF

$26 \quad 18839 \quad 1993: 2-2009: 1$

B F T BANQUE DE FINT ET DE

TRESORERIE

$\begin{array}{ll}27 & 18889\end{array}$

1993:2-2009:1

CORTAL CONSORS

$28 \quad 19239$

1993:2-2009:1

NATIXIS TRANSPORT FINANCE

$29 \quad 19269$

1993:2-2009:1

GENEBANQUE

$30 \quad 19870$

1993:2-2009:1

STE DES PAIEMENTS PASS - S2P

$31 \quad 22040$

1993:2-2009:1

CONFEDERATION NATIONALE

DU CREDIT MUTUEL

\section{2}

33

$30002 \quad 1993: 2-2009: 1$

CREDIT LYONNAIS

STE GENERALE

$34 \quad 30004$

1993:2-2009:1

BNP PARIBAS

$35 \quad 30027 \quad$ 1993:2-2009:1

CIN 


$\begin{array}{llll}36 & 30047 & 1993: 2-2009: 1 & \begin{array}{l}\text { CREDIT INDUSTRIEL DE L } \\ \text { OUEST }\end{array} \\ 37 & 30056 & 1993: 2-2009: 1 & \text { HSBC FRANCE } \\ 38 & 30066 & 1993: 2-2009: 1 & \text { CREDIT INDUSTRIEL ET COM- } \\ & & & \text { MERCIAL - CIC } \\ 39 & 30076 & 1993: 2-2009: 1 & \text { CREDIT DU NORD } \\ 40 & 30087 & 1993: 2-2009: 1 & \text { BANQUE CIC EST } \\ 41 & 30488 & 1993: 2-2009: 1 & \text { FORTIS BANQUE FRANCE } \\ 42 & 30568 & 1993: 2-2009: 1 & \text { BANQUE TRANSATLANTIQUE } \\ 43 & 30958 & 1993: 2-2009: 1 & \text { BNP PARIBAS LEASE GROUP } \\ 44 & 31489 & 1993: 2-2009: 1 & \text { CALYON } \\ 45 & 39996 & 1993: 2-2009: 1 & \text { GROUPE CREDIT AGRICOLE } \\ 46 & 40168 & 1993: 2-2009: 1 & \text { BANQUE DE BRETAGNE } \\ 47 & 41199 & 1993: 2-2009: 1 & \text { BANCO POPULAR FRANCE } \\ 48 & 42959 & 1993: 2-2009: 1 & \text { ELECTRO BANQUE } \\ 49 & 43799 & 1993: 2-2009: 1 & \text { BANQUE DE GESTION PRIVEE } \\ & & & \text { INDOSUEZ - BGPI } \\ 50 & 43899 & 1993: 2-2009: 1 & \text { UNION DE BANQUES ARABES ET } \\ & & & \text { FRSES U B A F } \\ 51 & 44449 & 1993: 2-2009: 1 & \text { LIXXCREDIT } \\ 52 & 50140 & 1993: 2-2009: 1 & \text { CMP-BANQUE }\end{array}$

\section{References}

Adrian, T., and H. S. Shin. 2009a. "Financial Intermediaries and Monetary Economics." Federal Reserve Bank of New York Staff Report No. 398 (October).

. 2009b. "Financial Intermediaries, Financial Stability, and Monetary Policy." In Maintaining Stability in a Changing Financial System, 287-334. Proceedings of the Federal Reserve Bank of Kansas City Economic Symposium at Jackson Hole, Wyoming, August 21-23, 2008.

- 2009c. "Prices and Quantities in the Monetary Policy Transmission Mechanism." Federal Reserve Bank of New York Staff Report No. 396 (October).

Angeloni, I., A. Kashyap, and B. Mojon, eds. 2003. Monetary Policy Transmission in the Euro Area. Cambridge: Cambridge University Press. 
Ashcraft, A. 2006. "New Evidence on the Lending Channel." Journal of Money, Credit, and Banking 38 (3): 751-76.

Bai, J., and S. Ng. 2002. "Determining the Number of Factors in Approximate Factor Models." Econometrica 70 (1): 191-221.

—. 2004. "A PANIC Attack on Unit-Roots and Cointegration." Econometrica 72 (4): 1127-77.

Bernanke, B. S. 1993. "How Important Is the Credit Channel in the Transmission of Monetary Policy? A Comment." CarnegieRochester Conference Series on Public Policy 39 (1): 47-52.

- 2004. "The Logic of Monetary Policy." Remarks before the National Economists Club, Washington, DC, December 2.

Bernanke, B. S., and A. S. Blinder. 1992. "The Federal Funds Rate and the Channels of Monetary Transmission." American Economic Review 82 (4): 901-21.

Bernanke, B. S., J. Boivin, and P. Eliasz. 2005. "Measuring the Effects of Monetary Policy: A Factor-Augmented Vector Autoregressive (FAVAR) Approach." Quarterly Journal of Economics 120 (1): 387-422.

Bernanke, B. S., and M. L. Gertler. 1995. "Inside the Black Box: The Credit Channel of Monetary Policy Transmission." Journal of Economic Perspectives 9 (4): 27-48.

Bernanke, B., and C. Lown. 1991. "The Credit Crunch." Brookings Papers on Economic Activity 2: 205-39.

Blinder, A. 1998. Central Banking in Theory and Practice. Cambridge, MA: MIT Press.

Boivin, J., and M. P. Giannoni. 2009. "Global Forces and Monetary Policy Effectiveness." In International Dimensions of Monetary Policy, ed. J. Galí and M. Gertler, 429-78. Chicago: University of Chicago Press.

Boivin, J., M. P. Giannoni, and B. Mojon. 2008. "How Has the Euro Changed the Monetary Transmission?" In NBER Macroeconomics Annual 2008, ed. D. Acemoglu, K. Rogoff, and M. Woodford. Chicago: NBER and University of Chicago Press.

Boivin, J., M. Gianonni, and D. Stevanovic. 2009. "Dynamic Effects of Credit Shocks in a Data-Rich Environment." Unpublished Manuscript, University of Montreal.

Candelon, B., and H. Lütkepohl. 2001. "On the Reliability of ChowType Tests for Parameter Constancy in Multivariate Dynamic Models." Economics Letters 73 (2): 155-60. 
Coffinet, J. 2005. "The Single Monetary Policy and the Interest Rate Channel in France and in the Euro Area." Banque de France Bulletin Digest 139 (July).

Commission bancaire. 2009. Rapport annuel de la Commission bancaire 2008. Paris: Banque de France.

Dave, C., S. J. Dressler, and L. Zhang. 2009. "The Bank Lending Channel: A FAVAR Analysis." Working Paper No. 4, Villanova School of Business Economics.

Den Haan, W. J., S. W. Sumner, and G. Yamashiro. 2007. "Bank Loan Portfolios and the Monetary Transmission Mechanism." Journal of Monetary Economics 54 (3): 904-24.

Ehrmann, M., L. Gambacorta, J. Martinez-Pagés, P. Sevestre, and A. Worms. 2001. "Financial Systems and the Role of Banks in Monetary Policy Transmission in the Euro Area." ECB Working Paper No. 105.

Ehrmann, M., and A. Worms. 2004. "Bank Networks and Monetary Policy Transmission." Journal of the European Economic Association 2 (6): 1148-71.

Engler, P., T. Jokipii, C. Merkl, P. Rovira Kaltwasser, and L. Vinhas de Souza. 2005. "The Effect of Capital Requirement Regulation on the Transmission of Monetary Policy: Evidence from Austria." Working Paper No. 99, Central Bank of Austria.

Gambacorta, L., and P. E. Mistrulli. 2004. "Does Bank Capital Affect Lending Behavior?" Journal of Financial Intermediation 13 (4): 436-57.

Giannone, D., M. Lenza, and L. Reichlin. 2009. "Monetary Analysis with Disaggregated Variables." Unpublished Manuscript, European Central Bank.

Gilchrist, S., V. Yankov, and E. Zakrajsek. 2009. "Credit Market Shocks and Economic Fluctuations: Evidence from Corporate Bond and Stock Markets." Journal of Monetary Economics 56 (4): 471-93.

Hülsewig, O., P. Winker, and A. Worms. 2004. "Bank Lending in the Transmission of Monetary Policy: A VECM Analysis for Germany." Jahrbücher für Nationalökonomie und Statistik (Journal of Economics and Statistics, Justus Liebig University Giessen, Department of Statistics and Economics) 224 (5): 511-29. 
Kashyap, A. K., and J. C. Stein. 1995. "The Impact of Monetary Policy on Bank Balance Sheets." Carnegie-Rochester Conference Series on Public Policy 42 (1): 151-95.

- 2000. "What Do a Million Observations on Banks Say about the Transmission of Monetary Policy?" American Economic Review 90 (3): 407-28.

Kilian, L. 1998. "Small-Sample Confidence Intervals for Impulse Response Functions." Review of Economics and Statistics 80 (2): 218-30.

Kishan, R. P., and T. P. Opiela. 2000. "Bank Size, Bank Capital and the Bank Lending Channel." Journal of Money, Credit, and Banking 32 (1): 121-41.

Loupias, C., F. Savignac, and P. Sevestre. 2002. "Is There a Bank Lending Channel in France? Evidence from Bank Panel Data." Notes d'Etudes et de Recherche No. 92, Banque de France.

Mésonnier, J.-S. 2008. "Bank Loan Portfolios, Bank Heterogeneity and the Bank Lending Channel: New Macro Evidence for France." Unpublished Manuscript.

Morgan, D. P. 1998. "The Credit Effects of Monetary Policy: Evidence Using Loan Commitments." Journal of Money, Credit, and Banking 30 (1): 102-118.

Ng, S., E. Moench, and S. Potter. 2009. "Dynamic Hierarchical Factor Models." Working paper presented at the NBER annual conference.

Peek, J., and E. Rosengren. 2000. "Collateral Damage: Effects of the Japanese Bank Crisis on Real Activity in the United States." American Economic Review 90 (1): 30-45.

Peek, J., E. Rosengren, and G. Tootell. 1999. "Is Bank Supervision Central to Central Banking?" Quarterly Journal of Economics 114 (2): $629-53$.

- 2003. "Identifying the Macroeconomic Effect of Loan Supply Shocks." Journal of Money, Credit, and Banking 35 (6): 932-46.

Ramey, V. 1993. "How Important Is the Credit Channel in the Transmission of Monetary Policy?" Carnegie-Rochester Conference Series on Public Policy 39 (1): 1-45.

Stock, J. H., and M. W. Watson. 1999. "Forecasting Inflation." Journal of Monetary Economics 44 (2): 293-335. 
- 2002. "Macroeconomic Forecasting Using Diffusion Indexes." Journal of Business and Economic Statistics 20 (2): $147-62$.

Van den Heuvel, S. K. 2002. "Does Bank Capital Matter for Monetary Policy Transmission?" Economic Policy Review (Federal Reserve Bank of New York) 8 (1): 259-65.

Woo, D. 2003. "In Search of 'Capital Crunch': Supply Factors behind the Credit Slowdown in Japan." Journal of Money, Credit, and Banking 35 (6): 1019-38.

Woodford, M. 2005. Central Bank Communication and Policy Effectiveness. Proceedings of the Federal Reserve Bank of Kansas City Economic Symposium at Jackson Hole, Wyoming, August 25-27. 